\title{
PENJALARAN KEBAKARAN PADA SUATU KONSTRUKSI BANGUNAN GEDUNG AKIBAT SUMBER PANAS
}

\author{
Maksum Tanubrata, Hendaryanto Wiryopranoto \\ Dosen Jurusan Teknik Sipil, Fakultas Teknik Universitas Kristen Maranatha \\ Jalan Prof.drg.Suria Sumantri, MPH 65, Bandung, 40164 \\ Email: maksum.tanubrata150@gmail.com \\ Email: hendaryanto_ws@yahoo.com
}

\begin{abstract}
ABSTRAK
Kebakaran adalah peristiwa oksidasi dari material yang berlangsung cepat, serta menghasilkan panas dan cahaya. Timbulnya kebakaran ditandai dengan penjalaran atau penyulutan suatu material oleh sumber panas. Penyulutan tersebut merupakan suatu permulaan dari pembakaran yang digunakan dalam peristiwa oksidasi. Bila api yang terjadi sangat terbatas, maka gejala tersebut belum dinyatakan sebagai kebakaran. Tetapi bila api mulai memungkinkan terjadinya penjalaran maka gejala itu dapat dikatakan sebagai kebakaran.
\end{abstract}

Kata kunci: Kebakaran, Penjalaran, Sumber Panas, Oksidasi

\begin{abstract}
Fire is the oxidation of the material events that took place quickly, as well as producing heat and light. Fire out breaks marked with raditation or ignition of material by a heat source. Firing it's a start of combution used in the event of oxidation. When fire occurs is limited, these symptoms have not been declared as a fire. But when the fire began to allow the propagation, the symptoms it can be said as a fire.
\end{abstract}

Keywords: Fire, Radiation, Heat Sources, Oxidizing.

\section{UNSUR - UNSUR DASAR PEMBAKARAN}

Pada dasarnya pembakaran dapat terjadi bila mempunyai tiga faktor utama yaitu Oksigen, Benda-benda mudah terbakar (Bahan Bakar), dan Energi Panas. Tiga faktor utama dari proses pembakaran tersebut dikenal dengan sebutan Fire Triangle. Pada Gambar 1 diperlihatkan diagram sederhana yang menunjukan kombinasi Fire Triangle. 
a). Bahan Bakar $<1>$, Oksigen $<2>$, dan Panas $<3>$, semuanya tersedia tetapi tidak ada pembakaran.

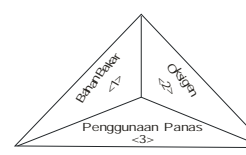

b). Penggunaan panas $<3>$ meningkat, permulaan reaksi antara bahan bakar dan oksigen terjadi, pembakaran di mulai

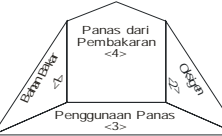

c). Oksigen dihilangkan, pembakaran berhenti

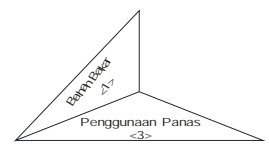

d). Bahan bakar dihilangkan pembakaran berhenti

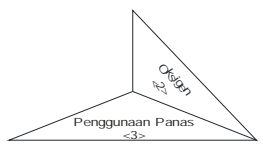

e). Penggunaan panas $<3>$ dihilangkan pembakaran masih berlangsung

f). Penggunaan panas $<3>$ dan panas yang dihasilkan dari pembakaran $<4>$ dihilangkan, pebakaran berhenti
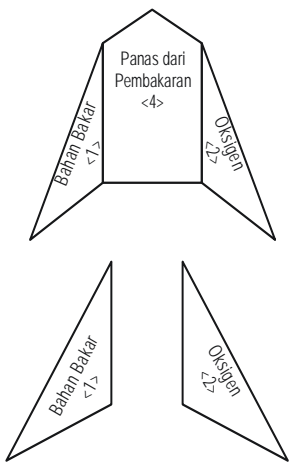

Gambar 1 Kombinasi tiga unsur pembakaran

\section{PERILAKU KEBAKARAN PADA RUANGAN TERBATAS}

Api bergerak ke atas secara cepat dengan cara konveksi dan dapat menjalar secara horizontal sepanjang langit-langit. Pembakaran tersebut mengembangkan gas menjadi gas panas dan berasap. Gas panas jika dibatasi akan cenderung meningkat (menyebar dengan cepat) mengisi seluruh ruangan. Pada Gambar 2 diperlihatkan bagaimana situasi sebuah ruangan yang mengalami kebakaran. 


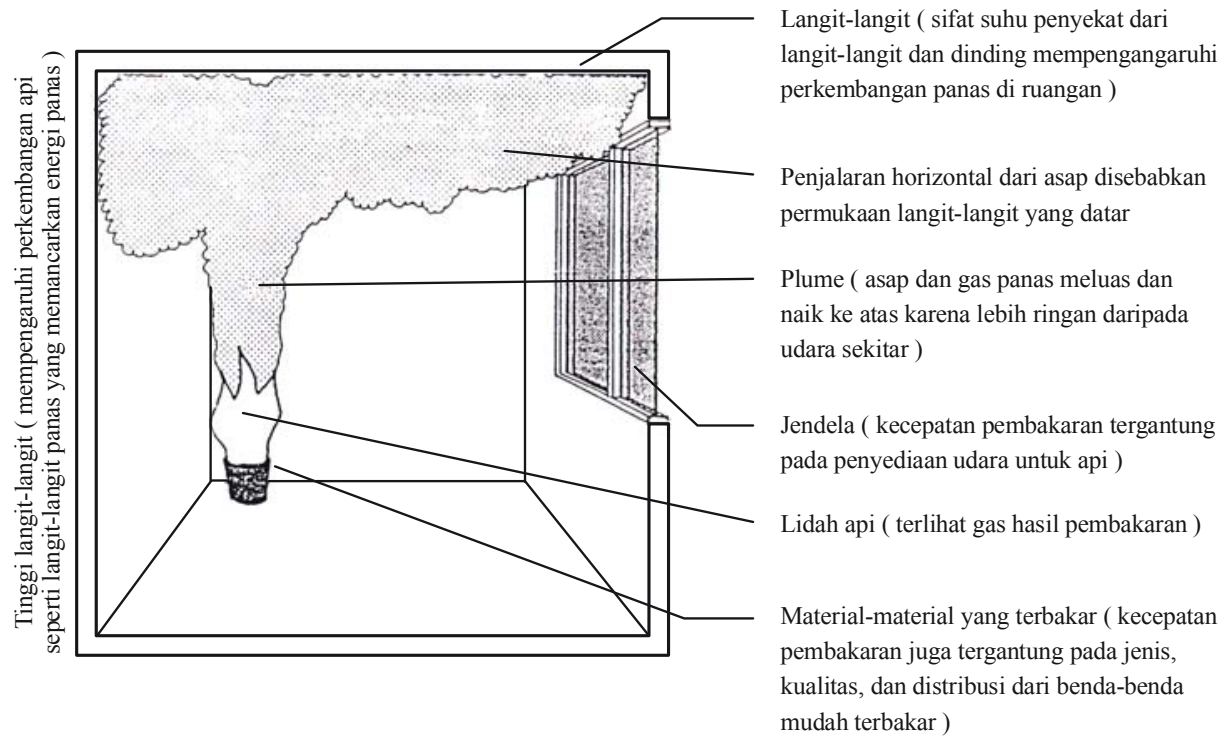

Gambar 2 Keranjang sampah yang terbakar pada ruangan

Temperatur pada asap yang berbentuk cendawan (plume) dapat menjadi tinggi sekitar $1200-1800^{\circ} \mathrm{F}$. Jika temperatur sekitar ruangan meningkat dengan cepat maka pengendalian kebakaran untuk menyelamatkan para penghuni tidak mungkin dilakukan dengan cara menghilangkan gas api secara cepat pula maka wajarlah bila pada umumnya kematian karena kebakaran disebabkan oleh asap dan gas berawan.

Gas panas yang menyebar dengan cepat serta energi radiasi dari langit-langit dan permukaan dinding bagian luar yang memanas, akan dengan cepat membakar semua material di dalam ruangan terutama bagian atas setelah itu akan merambat ke bagian bawah.

Semakin dekat langit-langit dengan materi yang terbakar, akan menjadi semakin panas. Langit-langit dan bahan lapisan dinding yang mudah terbakar akan membuat pengaruh penting pada perkembangan dan penyebaran api.

\section{PERILAKU MATERIAL TERHADAP KEBAKARAN}

Perilaku material terhadap kebakaran dapat kita artikan sebagai pencegah kebakaran secara pasif yang meliputi hal-hal sebagai berikut:

1. Menciptakan kompartemenisasi untuk suatu tipe bangunan guna meminimalkan penyebaran api dan asap.

2. Menjamin integritas dari kompartemen-kompartemen dalam hal terjadinya api, dengan memasang penyumbat api setiap lubang atau antara yang ada dari bagianbagian bangunan. 
3. Memasang insulasi panas guna mencegah kemungkinan terbakarnya sendiri bahanbahan yang mudah terbakar dengan transfer panas melalui elemen-elemen bangunan.

4. Melindungi elemen-elemen struktur dari perubahan bentuk dan ambruk, atau mengurangi sekecil-kecilnya biaya perbaikan yang berat dari beton yang rapuh kena panas api dalam hal terjadi di ruangan bawah tanah seperti basement dan tunnel.

Akibatnya penggunaan bahan-bahan atau material pencegahan api secara pasif, secara prinsip akan menghasilkan hal-hal sebagai berikut:

1. Dapat mencegah asap dan api dibatasi pada tempatnya untuk memberi waktu bertahan yang cukup terhadap api.

2. Evakuasi yang aman bagi para penghuni atau pemakai bangunan tanpa terjebak oleh api dan asap.

3. Menyediakan waktu yang cukup bagi para petugas pemadam kebakaran untuk mencapai lokasi tempat kebakaran. Hal tersebut jangan diabaikan, khususnya pada waktu-waktu jam-jam lalu lintas sedang sibuk dikota yang ramai.

4. Memungkinkan para petugas pemadam kebakaran untuk bekerja secepatnya dan seamannya ditempat yang bebas dari asap.

5. Meminimalkan kerusakan yang timbul.

Pemakaian bahan pencegahan terhadap kebakaran secara pasif harus dipadukan dengan sistem pencegahan terhadap kebakaran yang secara aktif. Pemakaian bahan pencegah terhadap kebakaran secara pasif akan menjamin standard keamanan yang lebih tinggi dan memberi solusi biaya yang efektif, bilamana penggunaan sistem pencegahan terhadap kebakaran secara aktif telah mencapai limitnya.

\section{METODE PENGENDALIAN KEBAKARAN}

Metode pengendalian kebakaran dapat kita artikan sebagai cara-cara penanggulangan bahaya kebakaran yaitu yang berarti mencegah meluasnya bahaya kebakaran dengan mengendalikan api yang timbul tanpa dikehendaki dan yang dapat mengarah pada terjadinya kebakaran.

Ada 3 pokok penyebab kebakaran yang dikategorikan sebagai berikut:

1. Kelalaian manusia:

a. Merokok tidak pada tempatnya.

Penjalaran Kebakaran Pada Suatu Konstruksi Bangunan Gedung Akibat Sumber Panas 
b. Kecerobohan penggunaan alat listrik.

c. Membuang bensin sambil merokok/menyalakan api.

d. Membuang puntung rokok berapi dalam tempat sampah kering.

e. Membiarkan saluran Elpiji $(L P G)$ bocor.

2. Kerusakan alat, motor listrik yang terbakar (hubungan singkat)

3. Unsur kesengajaan; SABOTAGE.

Selain itu 3 unsur pokok pencegahan kebakaran dapat dikelompokan seperti:

1. Usaha / aktifitas pencegahan.

2. Kesiapan peralatan / perlengkapan penanggulangan.

3. Kesiapan penyelamatan jiwa dan harta benda.

\section{TAKTIK PEMADAMAN DAN PERALATAN UNTUK MENCEGAH KEBAKARAN PADA SUATU GEDUNG}

Alat Pemadam Api Ringan (APAR) diklasifikasikan sesuai dengan tujuan penggunaan pada tiga kelas api A; B; C. Semua alat pemadam api ringan berperan dengan suatu daya padam yang menunjukan kecocokan pemadamannya untuk digunakan pada suatu kelas api tertentu

KELAS API:

\begin{tabular}{|c|c|c|}
\hline Kelas A & Kelas B & Kelas C \\
\hline $\begin{array}{cl}\text { Api dari bahan } \\
- & \text { Kayu } \\
& \text { listrik } \\
- & \text { Karet } \\
- & \text { Kain } \\
- & \text { Kertas }\end{array}$ & $\begin{array}{cl}\text { Api dari bahan } \\
\text { - } & \text { Terpentin } \\
\text { - } & \text { Bensin } \\
- & \text { Minyak } \\
\text { - } & \text { Cat }\end{array}$ & $\begin{array}{l}\text { Api dari bahan } \\
\text { - Peralatan }\end{array}$ \\
\hline
\end{tabular}

Dipadamkan Dipadamkan Dipadamkan

Metode Operasi Penggunaan APAR

Ambil dan bawa alat Pemadam Api Ringan (APAR) yang tersedia pada lokasi terdekat menuju sumber api, dalam jarak yang memungkinkan (4 meter dari sumber api), berhenti dan cabut Pen Pengunci serta hentakan Pemicu dengan tangan sebagai pengetesan kemampuan APAR, lalu arahkan pipa pemancar pada sumber api dengan jarak 1,5-2,5 meter sambil menekan pemicu. 
Sasaran pemadaman api dilakukan pada bagian atau sisi terdekat api dan selanjutnya bergerak maju dengan gerakan pipa pemancar secepatnya pada sisi lain dengan gerakan menyapu.

Untuk memadamkan api diperlukan prinsip pertahapan evakuasi agar pelaksanaan evakuasi berjalan dengan lancar, tertib, dan aman. Sebab jika tidak diatur pentahapannya akan terjadi kepanikan dan berdesak-desakan yang akan membahayakan bagi keselamatan karyawan yang akan menyelamatkan diri. Untuk gedung tinggi pentahapannya sebagai berikut:

1. Fase I lantai yang terbakar dan dua lantai diatasnya.

2. Fase II dua lantai dibawah lantai yang terbakar dan sisa diatas lantai yang terbakar.

3. Fase III sisa dari tahapan di atas yaitu lantai di bawah yang terbakar.

Pada gedung yang tinggi jalan keluar untuk evakuasi yang aman adalah tangga kebakaran, karena tangga kebakaran dilengkapi dengan system kedap asap (blower) sehingga diharapkan para penghuni gedung tinggi tidak menggunakan Lift atau Escalator, karena alat-alat tersebut dapat macet di tengah jalan akibat listrik otomatis padam jika terjadi kebakaran.

Langkah-langkah saat terjadi kebakaran:

1. Memberitahu telepon Operator dengan memutar tombol "Nol" dan menyebutkan nama pelapor dan lokasi terjadinya kebakaran.

2. Pecahkan dan tekan Fire Alarm glass terdekat yang ada pada bangunan atau gedung pada setiap Hydrant Box.

3. Gunakan APAR yang ada di tempat terdekat, untuk memadamkan api.

4. Mengikuti petunjuk evakuasi dari Fire Brigade (Tim Pemadam), dan jangan gunakan Lift (jika ada).

5. Jika mengetahui, matikan panel listrik jika penyebabnya adalah listrik. Tutup kran Gas, apabila penyebab kebakaran adalah kompor gas. 


\section{KEGANASAN API (FIRE SEVERITY)}

Untuk daerah di bawah kurva temperatur waktu, dapat digunakan untuk menggambarkan kekuatan potensial yang bersifat perusak yang dapat disebut sebagai Fire Severity atau Keganasan Api.

Keganasan dari api yang sebenarnya dapat dihubungkan dengan kurva temperatur waktu standard ASTM. Yaitu dengan menentukan daerah di bawah kurva standard yang sama dengan daerah di bawah kurva api yang sebenarnya. Sebagai contohnya api sebenarnya ditunjukan pada gambar kurva A dengan waktu pembakaran $\left(t_{1}\right)$ dimana sama dengan keganasan api di bawah standard kurva ASTM setelah waktu pembakaran yang lebih lama $\left(\mathrm{t}_{2}\right)$. Sebagai akibatnya waktu ketahanan api yang dilaporkan dari laboratorium test standard harus mempertimbangkan juga untuk waktu yang diperkirakan akan mengalami kegagalan yang dapat terjadi di bangunan-bangunan sebelum waktu yang telah dilaporkan atau diberikan.
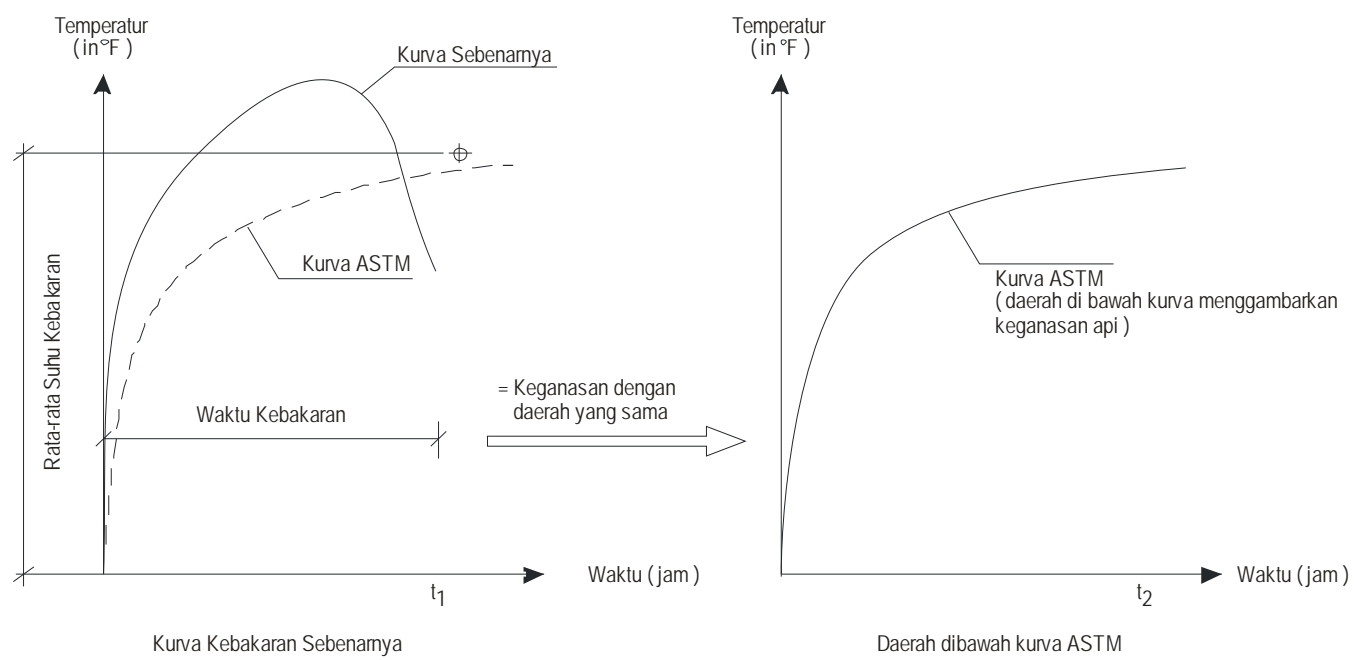

Dengan tambahan durasi kebakaran dan suhu kebakaran dari api yang telah menyala, keganasan kebakaran tergantung dari penyekatan kandungan arus panas di sekitar permukaan bangunan. Dimana ruang-ruang yang benar-benar terisolasi, panas yang terkandung di dalam ruangan akan meningkatkan pula besarnya kebakaran.

\subsection{Faktor-faktor Yang Mempengaruhi Keganasan Api}

Faktor-faktor utama yang menentukan dasar-dasar dari suatu kebakaran gedung atau suatu ruangan adalah adanya bahan-bahan yang mudah terbakar dan ventilasi ruangan. Dengan adanya bahan-bahan yang mudah terbakar dalam suatu bangunan dapat 
beraneka ragam macamnya dari kamar ke kamar dan dapat berubah dengan seiringnya waktu.

Dalam keadaan seperti itu memang sukar untuk memperkirakan api jika terjadi kebakaran sebagai akibatnya maka ketahanan api terhadap bangunan harus ditentukan dengan memperkirakan bahwa semakin banyak ventilasi maka kebakaran akan semakin sulit untuk dikendalikan.

\section{a. Ventilation Controlled}

Dimana adanya bahan-bahan yang mudah terbakar dan dengan sedikit ventilasi, seperti misalnya adanya basement, gedung-gedung dengan ruangan yang kecil dimana mempunyai lapisan yang tertutup, akan memakan waktu pembakaran yang lebih lama karena memiliki ventilasi yang tertutup. Dan pada waktu jendelanya pecah api akan menyebar dengan cepat.

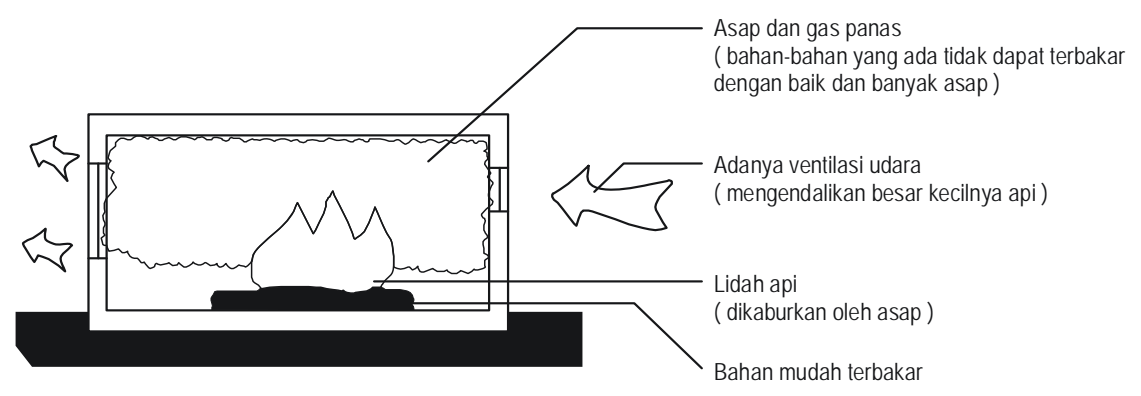

Gambar 3 Ventilation Controlled

\section{b. Fuel Controlled}

Apabila terdapat sedikit bahan-bahan yang mudah terbakar dan memilki ventilasi yang cukup (seperti misalnya bangunan dengan jendela yang besar dan dapat dibuka) maka api akan dapat dikendalikan dengan daerah dari permukaan bahan yang terbakar tersebut. Kebakaran dengan api yang dapat dikendalikan akan mempunyai waktu yang lebih singkat dan suhu ruangan tidak terlalu tinggi, hal ini karena disebakan oleh adanya pengaruh udara di luar ruangan yang lebih dingin.

Begitu pula dengan gedung-gedung bertingkat yang memiliki langit-langit yang rendah bagaimanapun juga jika terjadi kebakaran, api akan dapat menyebar dengan cepat dari lantai ke lantai melalui ruangan yang terbuka, bila langit-langitnya lebih tinggi, api akan lebih dapat diatasi atau dikendalikan hanya dalam ruangan itu saja. 


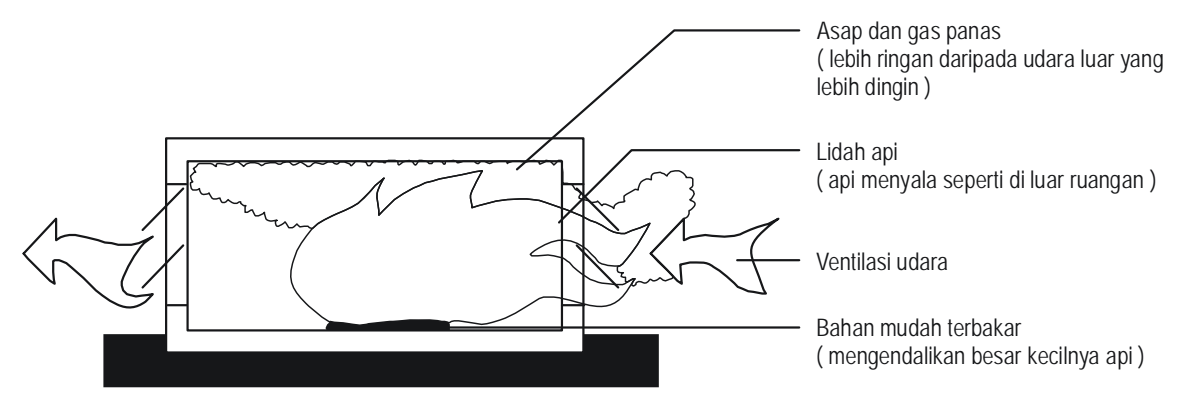

Gambar 4 Fuel Controlled

\section{FLASHOVER}

Hal yang patut diketahui adalah ketika flashover terjadi dalam Flashover biasanya diartikan sebagai pembakaran yang tiba-tiba dan terus menerus dari bahan-bahan yang mudah terbakar dan adanya gas-gas di dalam ruangan. Hal itu terjadi apabila temperatur ruangan dekat langit-langit naik dengan cepat dari $800-1200^{\circ} \mathrm{F}$., maka kesempatan untuk keluar dari ruangan sudah tidak ada. Kemungkinan untuk terjadinya flashover tidak dapat diketahui, karena perkembangan api sebelum terjadinya flashover bisa dalam waktu yang relatif singkat atau mungkin berjam-jam.

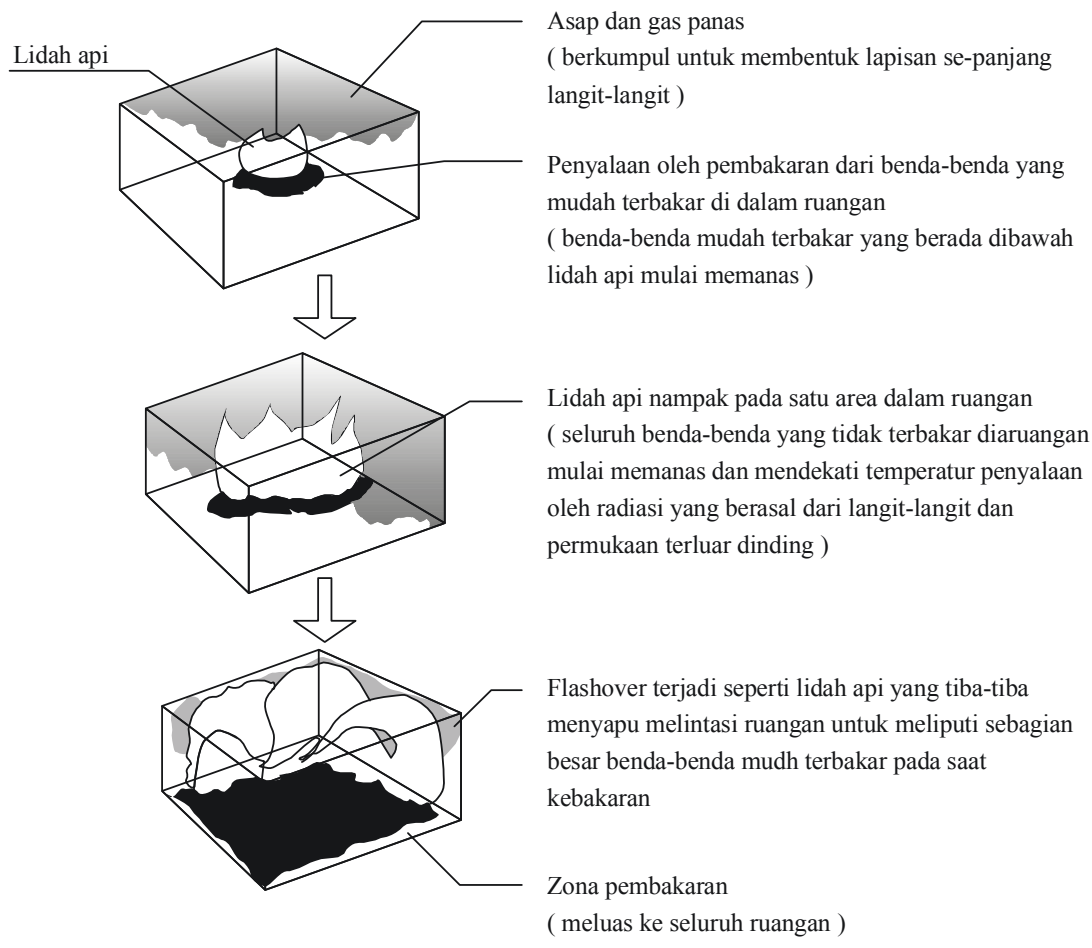

Gambar 5 Terjadinya Flashover 


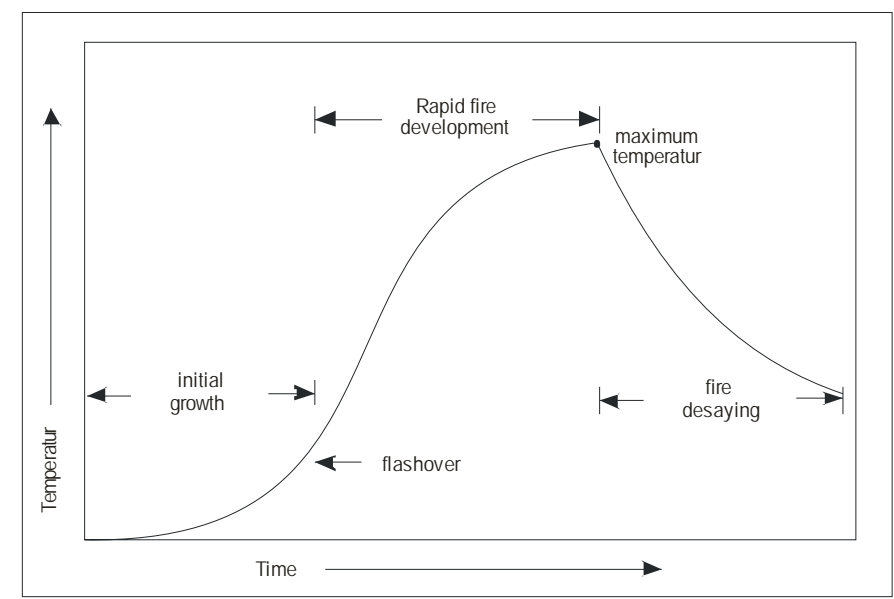

Gambar 6 Tahap-tahap Perkembangani

\section{MEMPERKIRAKAN KEGANASAN API}

Untuk membakar suatu material, dapat dilakukan dengan memperhitungkan kecepatan aliran udara yang masuk. Persamaan yang diberikan adalah sebagai berikut:

$$
\mathrm{V}^{`}=\mathrm{a} \cdot \mathrm{H}^{`} \cdot \mathrm{B} \cdot \mathrm{Vm}{ }^{`}
$$

Dimana: $\quad \mathrm{V}^{\top} \quad=$ kecepatan aliran udara yang masuk

$$
\begin{aligned}
\text { a } & =\text { koefisien pelepasan } \\
\mathrm{H}^{`} & =\text { tinggi dari bukaan (opening) di bawah garis netral } \\
\mathrm{B} & =\text { lebar jendela } \\
\mathrm{Vm}^{`} & \quad=\text { kecepatan rata-rata aliran udara yang masuk }
\end{aligned}
$$

Jika $\mathrm{L}$ adalah volume yang diperlukan untuk pembakaran $1 \mathrm{~kg}$ kayu , maka kecepatan membakar $\mathrm{R}=\mathrm{V}$ / $\mathrm{L}$ atau dengan persamaan sebagai berikut:

$$
\mathrm{R}=\frac{\mathrm{a} \cdot \mathrm{H}^{\prime} \cdot \mathrm{B} \cdot \mathrm{H} \cdot \mathrm{Vm}}{\mathrm{L}}
$$

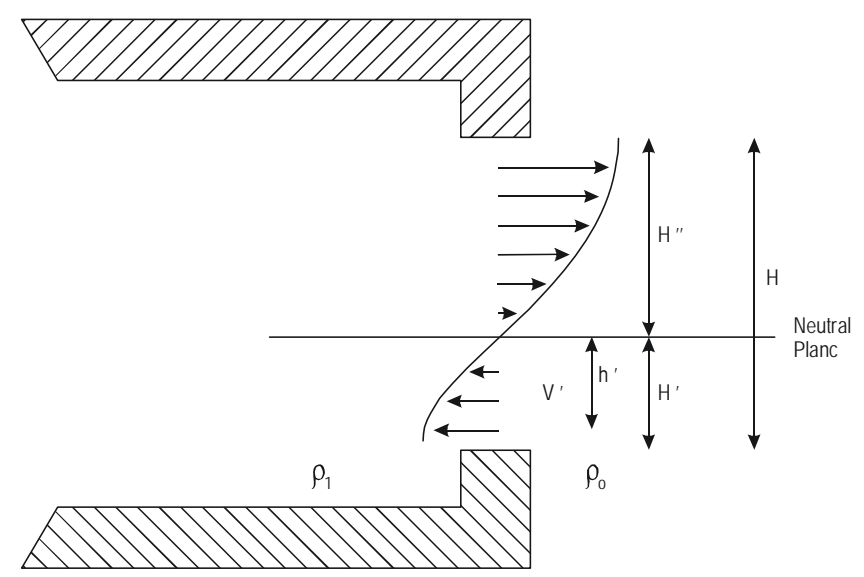

Gambar 7 Profil Kecepatan Udara melalui Opening

Penjalaran Kebakaran Pada Suatu Konstruksi Bangunan Gedung Akibat Sumber Panas 
Kecepatan rata-rata $\mathrm{Vm}^{\prime}$ dapat diperoleh dengan menghitung kcepatan lokal $\mathrm{V}^{\prime}$ dan mengambil rata-rata aliran udara yang masuk setinggi $\mathrm{H}^{\prime}$, kecepatan lokal dapat ditentukan dengan teorema Bernoulli's, dengan asumsi bahwa kepadatan gas di dalam ruangan adalah $\rho_{1}$ dan diluar ruangan adalah $\rho_{0}$, kecepatan $\mathrm{v}^{\prime}$ dapat diperkirakan dengan rumus :

$$
V^{\sigma}=\sqrt{2 g^{\prime} \frac{\rho_{0}-\rho_{1}}{\rho_{0}}}
$$

Kecepatan rata-rata yang lewat setinggi $\mathrm{H}^{`}$ adalah:

$$
\mathrm{Vm}^{\prime}=\frac{1}{\mathrm{H}} \int_{0}^{\mathrm{H}^{\prime}} \mathrm{V}^{\prime} \mathrm{dh}^{\prime}
$$

Dengan Integral didapat: $\quad \mathrm{Vm}^{\prime}=\frac{2}{3} \sqrt{2 \mathrm{gh}^{\prime} \frac{\rho_{0}-\rho_{1}}{\rho_{0}}}$

Dari persamaan 2 dan 5 dapat diketahui bahwa kecepatan membakar $\mathrm{R}$ adalah sebanding dengan $\mathrm{H}^{\prime} \times \mathrm{B} \times \mathrm{H}^{\prime}$. Jika $\mathrm{H}^{\prime}$ diasumsikan sebanding dengan tinggi jendela $\mathrm{H}$, maka kecepatan membakar sebanding dengan $\mathrm{H}$ x B x $\mathrm{H}$, maka di dapat persamaan akhir

$$
\text { : } \quad \mathrm{R}=\mathrm{CA} \sqrt{\mathrm{R}}
$$

dimana C merupakan harga konstan dari hasil percobaan Kawagoe dan Sekine dengan nilai yang dapat diberikan berkisar 5,0 sampai dengan 6,2. Sedangkan $\mathrm{A}=\mathrm{HB}$ adalah Luas Opening atau luas jendela pada ruangan tertutup $\mathrm{A} \sqrt{\mathrm{H}}$ dapat disebut dengan faktor ventilasi.

Percepatan kecepatan membakar tersebut yang memperhitungkan beberapa faktor, seperti sifat material dinding, ukuran ruangan tertutup, kenaikan temperatur dari pembakaran, durasi dan periode kehancuran. Hasil akhir persamaan yang diperoleh adalah:

$$
\mathrm{R}=5,5 \mathrm{~A} \sqrt{\mathrm{H}}
$$




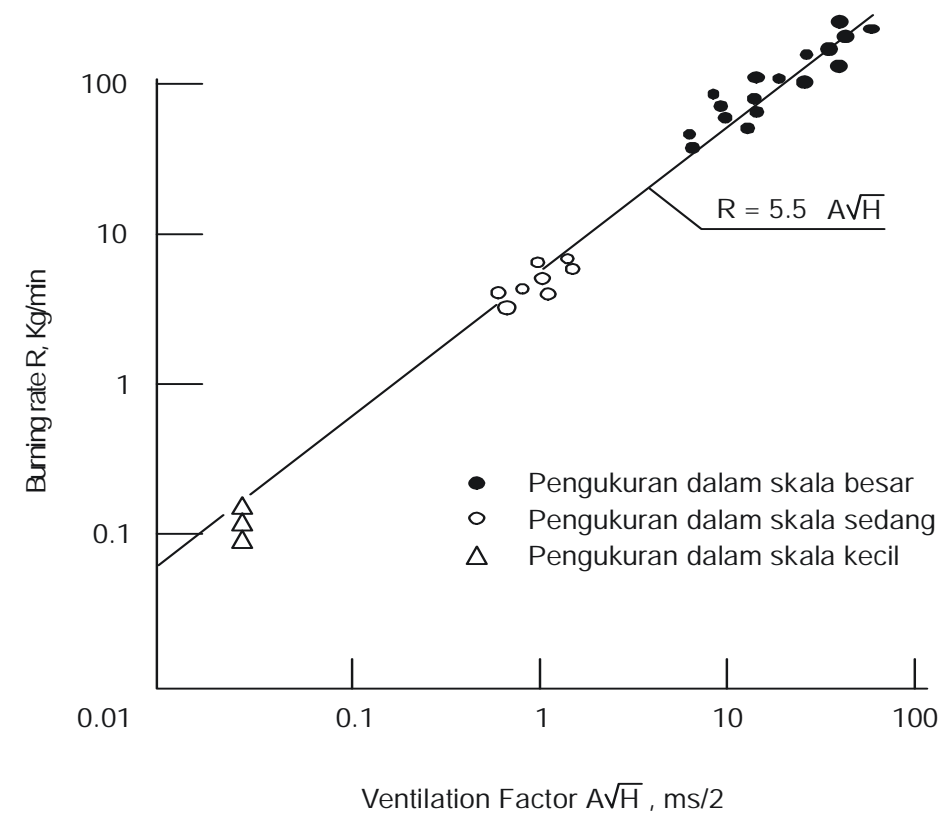

Gambar 8. Hasil percobaan yang dilakukan Kawagoe dan Sekine untuk menguji kecepatan pembakaran dalam ruangan sebagai fungsi dari luas dan tinggi jendela.

\section{KESEIMBANGAN PANAS PADA RUANGAN}

Perubahan temperatur selama kebakaran pada ruangan, dapat dihitung melalui keseimbangan panas untuk ruangan tersebut. Faktor-faktor yang menyediakan panas untuk ruangan selama kebakaran adalah:

1. Pembakaran material pada ruangan tersebut

2. Aliran udara yang masuk mempunyai kandungan panas terten Gambar 9 Keseimbangan Panas dalam Ruangan selama Kebakaran [2]

Sedangkan penyebab kehilangan panas antara lain:

a. Konduksi pada dinding

b. Penuaian gas pada ruangan

c. Perpindahan panas ke sekeliling ruangan oleh radiasi melalui bukaan (opening)

d. Konveksi gas

Dengan factor-faktor penyediaan dan kehilangan panas tersebut, maka kesimbangan panas untuk ruangan dapat ditulis dengan persamaan:

$$
\mathrm{Q}_{\mathrm{C}}+\mathrm{Q}_{\mathrm{I}}=\mathrm{Q}_{\mathrm{W}}+\mathrm{QR}_{\mathrm{R}}+\mathrm{Q}_{\mathrm{L}}+\mathrm{Q}_{\mathrm{G}}
$$

Dimana:

$$
\begin{aligned}
& \mathrm{Q}_{\mathrm{C}}=\text { panas yang dihasilkan dalam ruangan tiap satuan waktu oleh pembakaran } \\
& \text { material } \\
& \mathrm{Q}_{\mathrm{I}}=\text { panas yang disediakan oleh aliran udara masuk tiap satuan waktu }
\end{aligned}
$$


$\mathrm{Q}_{\mathrm{W}}=$ panas yang diserap oleh dinding tiap satuan waktu

$\mathrm{Q}_{\mathrm{R}}=$ panas yang hilang oleh radiasi melalui opening tiap satuan waktu

$\mathrm{Q}_{\mathrm{L}}=$ panas yang hilang oleh aliran keluar gas tiap satuan waktu

$\mathrm{Q}_{\mathrm{G}}=$ panas yang diserap oleh gas dalam ruangan tiap satuan waktu

Penentuan Perubahan Temperatur Kebakaran

Perubahan temperatur (temperatur course) kebakaran pada ruangan dapat ditentukan dengan persamaan 8. Namun perubahan temperatur yang ditentukan pada persamaan 8 tergantung pada banyak faktor, sehingga sulit untuk memperkirakan keadaan yang sebenarnya. Berdasarkan persamaan yang dilakukan Kawagoe dan Sekine, persamaan 8 tersebut dikembangkan sedemikian rupa, sehingga pada penentuan perubahan temperatur, secara kuantitas hanya tergantung pada faktor opening $\left(\mathrm{F}_{0}\right)$ dan durasi kebakaran ( $\mathrm{t}) . \mathrm{F}_{0}$ dan $\mathrm{t}$ dapat didefinisikan:

$$
\begin{aligned}
\mathrm{F}_{0} & =\frac{\mathrm{A} \sqrt{\mathrm{H}}}{\mathrm{At}} \\
\mathrm{t} & =\mathrm{W} \cdot \mathrm{Fd}=\frac{\mathrm{W} \mathrm{A}}{330 \mathrm{~A} \sqrt{\mathrm{H}}}
\end{aligned}
$$

Dimana: $\quad \mathrm{A}=$ luas jendela dari ruangan $\left(\mathrm{m}^{2}\right)$

$\mathrm{H}=$ tinggi jendela $(\mathrm{m})$

At $=$ luas permukaan dinding dalam ruangan $\left(\mathrm{m}^{2}\right)$

$\mathrm{A}_{\mathrm{F}}=$ luas lantai $\left(\mathrm{m}^{2}\right)$

$\mathrm{W}=$ fire load density $\left(\mathrm{kg} / \mathrm{m}^{2}\right)$

$F_{d}=$ faktor durasi kebakaran yang ditentukan oleh Kawagoe dan

Sekine $\left(\mathrm{m}^{2} . \mathrm{jam} / \mathrm{kg}\right)$

Odeen berpendapat bahwa fire load setiap satuan luas dinding sebanding dengan fire load tiap satuan luas lantai. Maka pada persamaan 10, durasi fire load dapat juga menggunakan persamaan:

$$
\mathrm{t}=\frac{1}{330} \frac{\mathrm{W}}{\mathrm{F}_{0}}
$$

Dimana: $\quad \mathrm{W}=$ fireload density $\left(\mathrm{kg} / \mathrm{m}^{2}\right)$

$\mathrm{F}_{0}=$ factor opening (lihat persamaan 9)

Pada Gambar 11 diperlihatkan kurva temperatur kebakaran yang dibuat oleh Kawagoe dan Sekine. Percobaan perubahan temperatur yang dilakukan oleh Kawagoe dan Sekine tersebut, untuk material dinding ringan didasarkan pada konduktifitas 0,5 $\mathrm{kcal} / \mathrm{mh}^{0} \mathrm{C}$ dan untuk material dinding berat didasarkan pada konduktifitas $0,1 \mathrm{kcal} / \mathrm{mh}^{0} \mathrm{C}$, dimana keduanya menggunakan diffusivity $0,002 \mathrm{~m}^{2} / \mathrm{h}$. Pada prakteknya ,untuk 
menghitung temperatur maksimum kebakaran dapat diasumsikan, bahwa kurva untuk material dinding berat dapat digunakan jika kepadatan dinding ruangan, lebih besar atau sama dengan $1600 \mathrm{~kg} / \mathrm{m}^{3}$, dan kurva untuk material dinding ringan dapat digunakan jika kepadatan dinding ruangan kurang dari $1600 \mathrm{~kg} / \mathrm{m}^{3}$.

Durasi tahap pembakaran (duration of the burning period) ditujukan oleh t. Setelah t dilampaui maka temperatur kebakaran mulai menghancurkan. Berdasarkan percepatan Kawagoe dan Sekine, jika $\mathrm{t} \geq 1$ jam maka kecepatan penurunan temperatur adalah $7{ }^{\circ} \mathrm{C}$ per menit dan jika $\mathrm{t}<1$ jam maka kecepatan penurunan temperatur adalah $10{ }^{\circ} \mathrm{C} /$ menit.

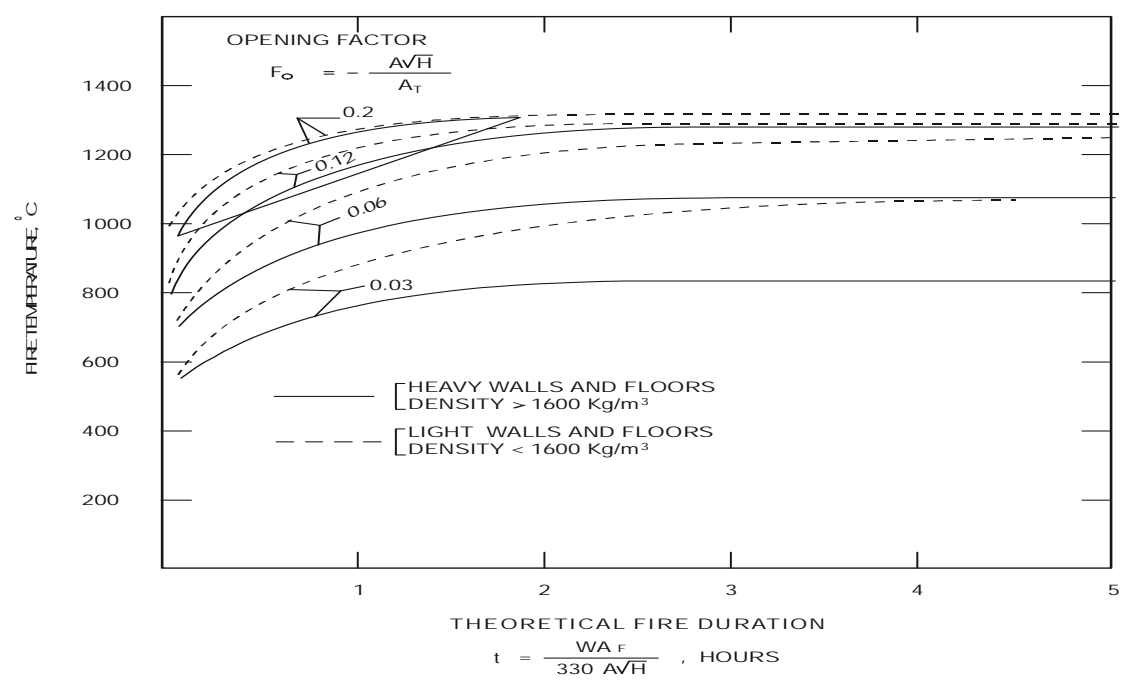

Gambar 9 Temperatur Kebakaran sebagai Fungsi dari Durasi Kebakaran dalam Ruangan yang menggunakan dinding ringan dan dinding berat untuk berbagai macam harga $\mathrm{F}_{0}$

\section{Menentukan Fire Load Density}

Fire Load merupakan jumlah dari benda-benda terbakar yang terdapat pada bangunan karena fire load terdiri atas berbagai macam material yang secara kuantitas berbeda, maka fire load dapat dinyatakan sehingga kayu akivalen dengan mengkonversikan nilai kalori kayu sebesar $8000 \mathrm{Btu} / \mathrm{lb}$ atau 4444 kkal/kg. Kayu ekivalen ini menunjukan jumlah $1 \mathrm{~kg}$ kayu yang terkandung dalam $1 \mathrm{~kg}$ material. Umumnya fire load dinyatakan setiap $1 \mathrm{~m}^{2}$ luas lantai / berdasarkan kepadatan beban api (fire load density). Fire Load Density dapat dihitung dengan formula sebagai berikut : 


$$
\mathrm{FL}=\frac{\sum(\mathrm{q} \mathrm{w})}{4444 \mathrm{~A}_{\mathrm{F}}}
$$

Dimana: $\quad \mathrm{FL} \quad=$ fire load $\left(\mathrm{kg} / \mathrm{m}^{2}\right)$

$\mathrm{q}=$ nilai kalori dari benda mudah terbakar $(\mathrm{kkal} / \mathrm{kg})$

$\mathrm{W}=$ berat benda mudah terbakar $(\mathrm{kg})$

$\Sigma \mathrm{qw}=\mathrm{q}_{1} \mathrm{~W}_{1}+\mathrm{q}_{2} \mathrm{~W}_{2}+\ldots \ldots \mathrm{q}_{\mathrm{n}} \mathrm{W}_{\mathrm{n}}$

$\mathrm{A}_{\mathrm{F}} \quad=$ luas lantai $\left(\mathrm{m}^{2}\right)$

Contoh Memperkirakan Temperatur Course

Pada percobaan yan dilakukan Kawagoe dan sekine digunakan ruangan yang mempunyai karakteristik sebagai berikut:

$\mathrm{A}=$ luas jendela $=1,67 \mathrm{~m}^{2}$

$\mathrm{H}=$ tinggi jendela $=1,8 \mathrm{~m}$

$\mathrm{At}=$ luas total permukaan dinding dalam ruangan $=48 \mathrm{~m}^{2}$, dinding terbuat dari

blok-blok beton dipertimbangkan sebagai material berat dengan kepadatan material lebih besar dari $1600 \mathrm{~kg} / \mathrm{m}^{3}$

$\mathrm{A}_{\mathrm{F}}=$ luas lantai $=9 \mathrm{~m}^{2}$

$\mathrm{W}=$ fire load tiap luas lantai $=100 \mathrm{~kg} / \mathrm{m}^{2}$

Apabila dihitung dengan secara teoritis dengan menggunakan persamaan 9 dan 10 maka:

$$
\begin{aligned}
\mathrm{F}_{0} & =\frac{1.67 \sqrt{1.8}}{48}=0,047 \mathrm{~m}^{1 / 2} \\
\mathrm{t} & =\frac{100 \times 9}{330 \times 1.67 \times \sqrt{1.8}}=1,22 \mathrm{jam}
\end{aligned}
$$

Hasil $\mathrm{F}_{0}=0,047 \mathrm{~m}^{1 / 2}$ dan $\mathrm{t}=1,22$ jam di plot pada gambar 2.11 maka di dapat temperatur maximum yang dapat dicapai oleh kebakaran sekitar $910{ }^{0} \mathrm{C}$. Jadi dengan karakteristik ruangan tersebut, durasi tahap pembakaran (duration of the burning period) dapat berlangsung selama 1,22 jam. Setelah waktu tersebut dilampaui, tahap penghancuran (decay period) oleh api kebakaran dimulai. Karena durasi tahap pembakaran t lebih besar dari 1 jam, sesuai dengan data percobaan kecepatan penurunan temperatur yang terjadi adalah $7{ }^{0} \mathrm{C}$ setiap menit. Sehingga waktu yang diperlukan untuk mencapai temperatur $400{ }^{0} \mathrm{C}$ setelah temperatur maksimum dicapai adalah $(910-400) / 7=72,86$ menit $=1,21$ jam, untuk lebih jelasnya tahap-tahap perubahan temperatur dapat dilihat pada Gambar 10

Akan halnya dengan hasil pengukuran dari percobaan yang dilakukan oleh Kawagoe dan sekine, dimana pengukuran dilakukan pada beberapa tempat dalam ruangan 
yang mempunyai data-data seperti diatas. Hasil pengukuran yang berupa perubahan temperatur di beberapa tempat tersebut dicatat setiap 15 menit selama 2 jam, sehingga didapat kurva seperti pada Gambar 10.

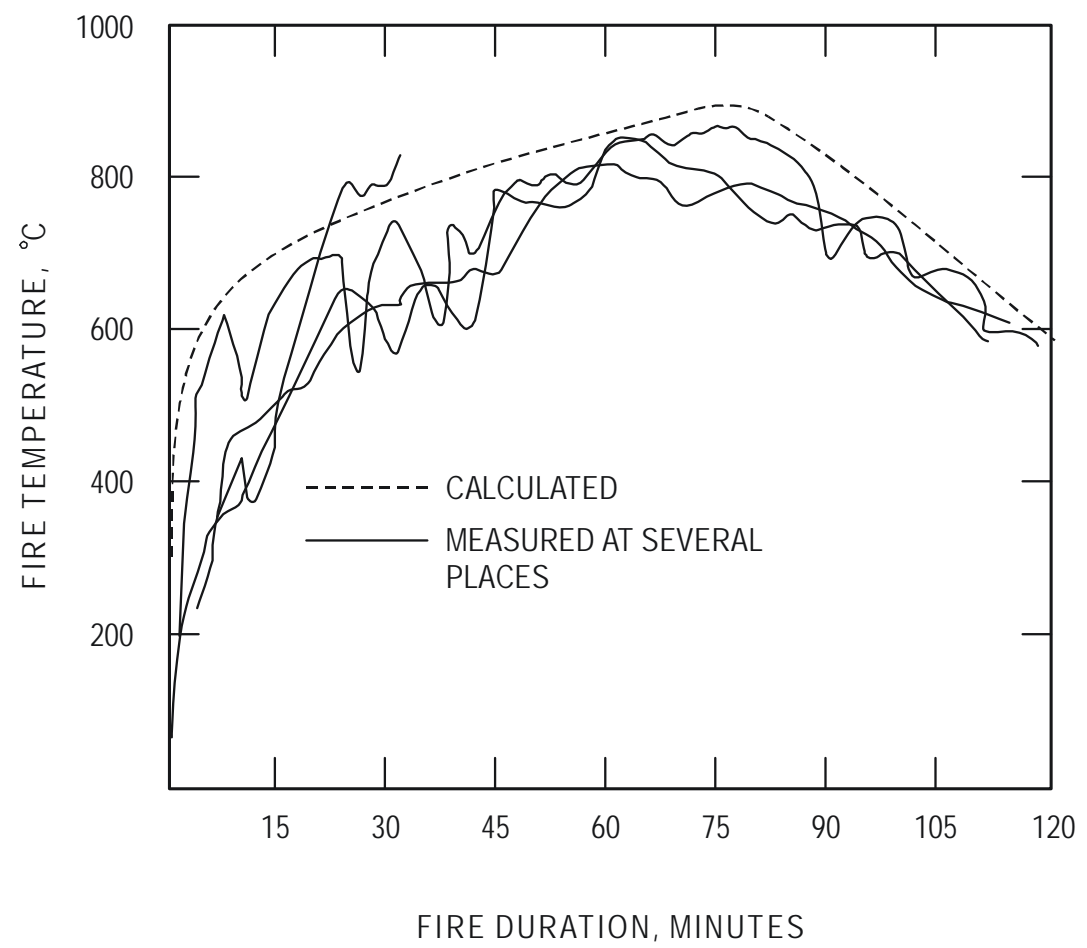

Gambar 10 Perkiraan dan pengukuran temperatur dalam percobaan kebakaran

\subsection{Daya Tahan api}

Dapat didefinisikan sebagai kemampuan dari suatu bahan atau material suatu konstruksi bangunan untuk suatu periode waktu tertentu tanpa kehilangan fungsinya, misal menahan beban. Telah dibuat suatu kurva yang menghubungkan temperatur dan waktu selama kebakaran dengan beban api dan ventilasi (besar lubang udara) yang berbeda-beda. Kurva dapat dilihat pada Gambar 12.

Kurva yang dibuat oleh Butcher et al. itu adalah sutau hasil percobaan dalam suatu ruang dari tembok bata berukuran $(3,7 \times 7,7 \times 3) \mathrm{m}$ dengan ventilasi diatur sebesar $25 \%$ dan $50 \%$ luas bidang satu dinding vertikal dengan dua buah jendela setinggi $1,8 \mathrm{~m}$. Maka arti kurva $60(1 / 2)$ adalah kepadatan beban api sebesar $60 \mathrm{~kg}$ setiap $1 \mathrm{~m}^{2}$ luas lantai dan mempunyai lubang ventilasi sebesar $50 \%$ dari suatu dinding. 


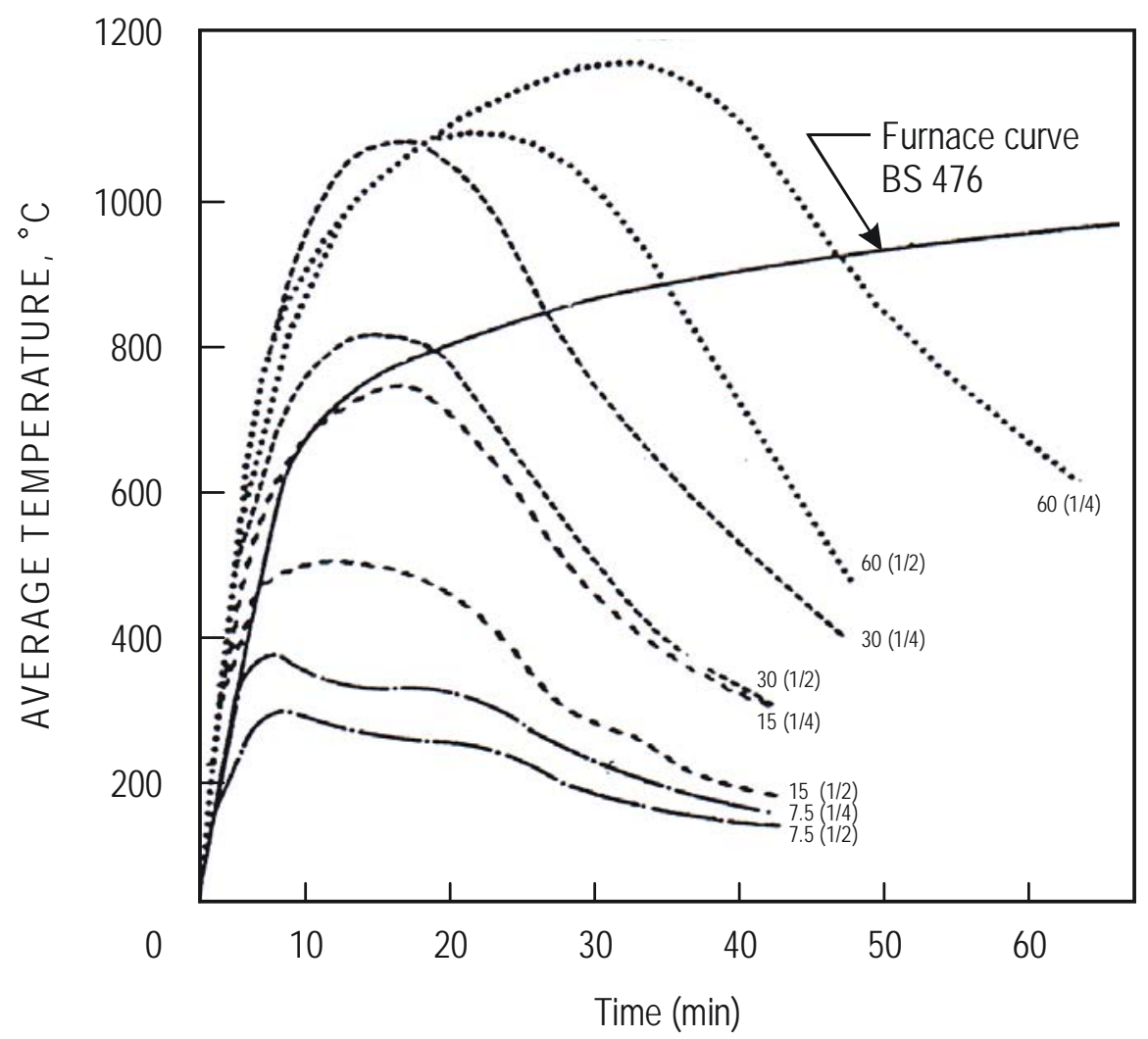

Gambar 11 Pengaruh fire load density dan ventilasi pada perubahan temperatur

Pembebanan pada percobaan dimaksudkan agar sesuai dengan keadaan yang sebenarnya. Namun pada percobaan yang dilakukan tersebut harus mengasumsikan bahwa panas yang ditransfer ke elemen struktur adalah lebih besar daripada panas yang ditransfer melalui tungku pemanasan yang bukan keadaan sebenarnya. Efek ini hanya berlangsung pada tahap permulaan saja, kurang lebih 20 sampai dengan 30 menit pertama. Kesulitan lain yang dihadapi adalah mengenai pembebanan. Pembebanan pada keadaan sebenarnya adalah beban merata.

\section{PERPINDAHAN PANAS}

Perpindahan panas (heat transfer) yang terjadi pada saat bangunan mengalami kebakaran adalah secara konveksi, konduksi, dan radiasi.

\subsection{Konveksi}

Konveki adalah perpindahan panas melalui gerakan udara, sebagian panas yang dihasilkan pada permukaan material, ditransmisikan ke udara dan membentuk gas-gas 
panas. Karena meningkatnya temperatur, berat jenis gas-gas panas ini berkurang dibandingkan dengan udara sekitarnya. Sehingga gas-gas panas ini, cenderung menyebar dan mencari daerah yang lebih tinggi, disertai pembentukan cendawan api (fire plume). Jumlah panas/kalor yang dipindahkan dari cendawan api ini, menentukan jumlah uap panas yang menyebabkan kebakaran. Selama kebakaran terjadi, uap panas ini meluas dan bergerak menjauh dari sumber kebakaran, menggunakan tekanan untuk melawan pintu dan berusaha menembus opening seperti jendela dan ventilasi, sehingga tidak mustahil, apabila seluruh kaca dalam ruangan akan pecah sebelum keganasan api timbul.

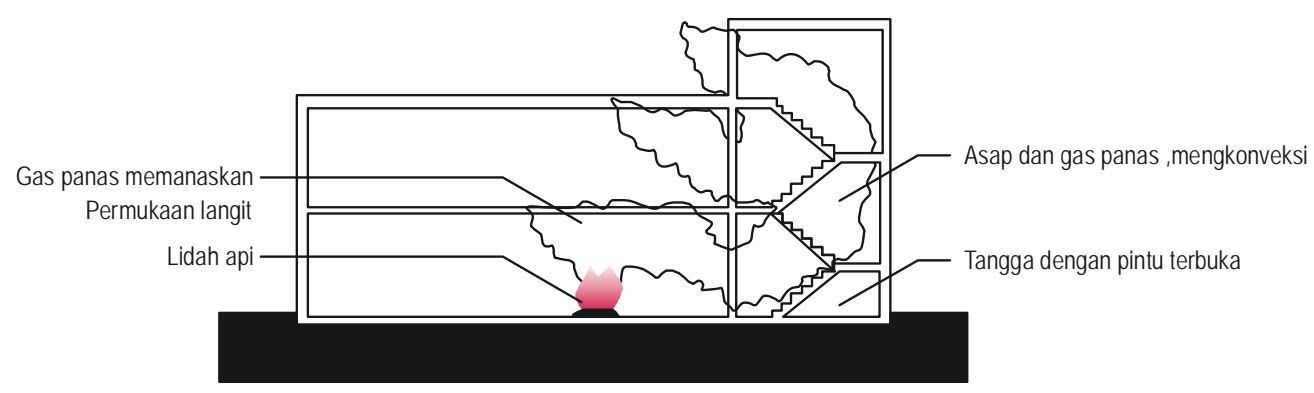

Gambar 12 Konveksi

\subsection{Konduksi}

Konduksi adalah perpindahan panas melalui material-material padat. Sebagian panas yang terjadi pada permukaan bahan bakar (material padat) disalurkan kembali ke bagian bahan bakar yang belum terbakar. Energi panas ini memberikan panas awal sebelum permukaan bahan bakar mengalami vaporasi (penguapan akibat kebakaran). Selama kebakaran terjadi, panas dapat dipindahkan melalui balok baja, kawat/kabel, pipa logam, dinding dan berbagai material lain yang pada saat menghantarkan panas material tersebut belum mengalami kehancuran.

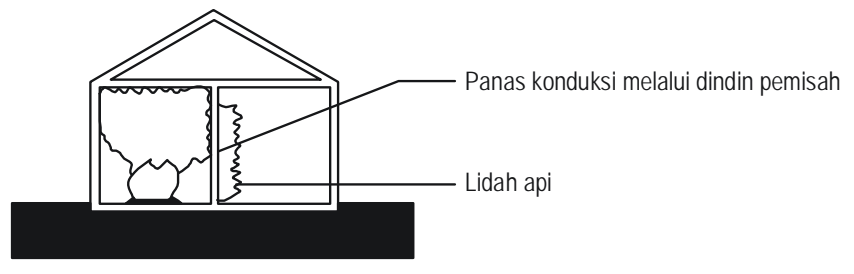

Gambar 13 Konduksi

Hubungan dasar yang menyatakan laju aliran panas / heat transfer secara konduksi dikenal sebagai Hukum Fourier, dengan formula sebagai berikut: 


$$
\frac{\mathrm{q}}{\mathrm{A}}=-\mathrm{k} \frac{\vartheta \mathrm{T}}{\vartheta \mathrm{x}}
$$

$$
\begin{aligned}
\text { Dimana : A } & =\text { Luas permukaan }\left(\mathrm{m}^{2}\right) \\
\mathrm{X} & = \\
& \text { Jarak dari permukaan yang diukur secara tegak lurus terhadap } \\
& \text { permukaan }(\mathrm{m}) \\
\mathrm{q} \quad & \text { Laju alir panas melalui permukaan, dalam arah tegak lurus ter- } \\
& \text { hadap permukaan tersebut (watt }=\text { joule/detik) } \\
\mathrm{T} & =\text { Temperatur }(\mathrm{K}) \\
\mathrm{k} & =
\end{aligned}
$$

Tanda (-) mencerminkan fakta bahwa panas mengalir dari tempat panas ke tempat dingin.

Pada Gambar 14 diperlihatkan aliran panas sebagai akibat adanya perubahan temperatur/gradien temperatur. Pada keadaan awal, suatu material mempunyai temperatur yang relatif sama dengan temperatur sekitar/suhu kamar. Ketika material tersebut terkonduksi oleh panas yang bertemperatur $T_{1}$, maka partikel-partikel material akan mengalami perubahan temperatur secara bertahap menurut waktu dan kedudukan $(\Delta x)$, serta mengakibatkan aliran panas yang melalui setiap partikel tidak konstan. Kondisi demikian disebut unsteady state.

Setelah panas yang dikonduksikan berlangsung lama, maka partikel-partikel material tidak mengalami perubahan temperatur lagi. Jika terjadi perubahan, perubahan yang ditimbulkan sangat kecil. Sehingga dapat dikatakan perubahan temperatur bersifat linier menurut $\Delta_{\mathrm{x}}$ dan dicapailah suatu aliran panas (W) yang konstan di setiap partikel. Kondisi demikian disebut steady state.

Untuk memudahkan analisis heat transfer, aliran panas diasumsikan telah mencapai kondisi steady state. Dengan demikian tidak memperhitungkan perubahan temperatur terhadap waktu, melainkan hanya berdasarkan kedudukan $\left(\Delta_{\mathrm{x}}\right)$ atau dalam kenyataannya merupakan tebal material. 


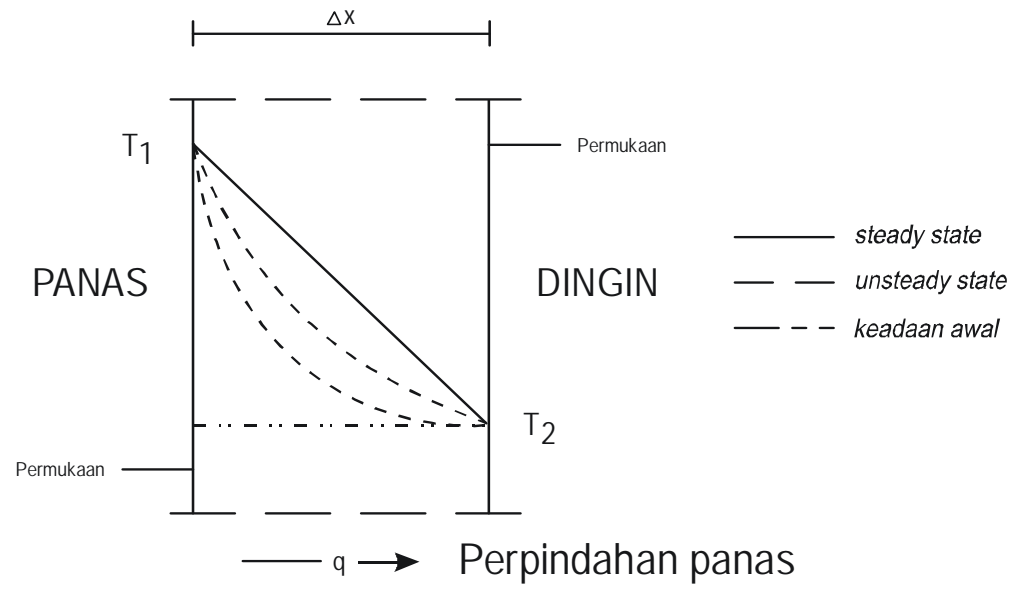

Gambar 14 Gradien temperatur pada suatu material yang terkonduksi

Sehingga Hukum Fourier pada Persamaan 13 tersebut dapat dikembangkan lebih lanjut untuk menganalisis perpindahan panas melalui dinding yang terdiri atas beberapa lapis atau material. Pada Gambar 15 diperlihatkan aliran panas melalui dinding yang terdiri atas beberapa lapis, dan gradien temperatur $T_{1}, T_{2}, T_{3}, T_{4}$, telah mencapai steady state. Aliran panas yang mengalir pada tiap lapis $\mathrm{A}, \mathrm{B}$, dan $\mathrm{C}$ adalah sama.

$$
\mathrm{q}=\frac{\mathrm{k}_{\mathrm{A}} \times \mathrm{A}}{\Delta \mathrm{x}_{\mathrm{A}}} \mathrm{T}_{1}-\mathrm{T}_{2}=\frac{\mathrm{k}_{\mathrm{B}} \times \mathrm{A}}{\Delta \mathrm{x}_{\mathrm{B}}} \mathrm{T}_{2}-\mathrm{T}_{3}=\frac{\mathrm{k}_{\mathrm{c}} \times \mathrm{A}}{\Delta \mathrm{x}_{\mathrm{c}}} \mathrm{T}_{3}-\mathrm{T}_{4}
$$

Untuk menentukan hubungan masing-masing temperatur $T_{1}, T_{2}, T_{3}, T_{4}$, adalah sebagai berikut :

$$
\begin{aligned}
& \mathrm{T}_{1}=\mathrm{q} \frac{\Delta \mathrm{x}_{\mathrm{A}}}{\mathrm{k}_{\mathrm{A}} \mathrm{x}}+\mathrm{T}_{2} \\
& \mathrm{~T}_{2}=\mathrm{q} \frac{\Delta \mathrm{x}_{\mathrm{B}}}{\mathrm{k}_{\mathrm{B}} \mathrm{x}}+\mathrm{T}_{3} \\
& \mathrm{~T}_{3}=\mathrm{q} \frac{\Delta \mathrm{x}_{\mathrm{C}}}{\mathrm{k}_{\mathrm{C}} \mathrm{x}}+\mathrm{T}_{4}
\end{aligned}
$$

Apabila persamaan 15, 16, 17 disubstitusikan maka akan didapat

$$
\mathrm{q}=\frac{\mathrm{T}_{1}-\mathrm{T}_{4}}{\frac{\Delta \mathrm{x}_{\mathrm{A}}}{\mathrm{k}_{\mathrm{A}} \mathrm{xA}}+\frac{\Delta \mathrm{x}_{\mathrm{B}}}{\mathrm{k}_{\mathrm{B}} \mathrm{xA}}+\frac{\Delta \mathrm{x}_{\mathrm{C}}}{\mathrm{k}_{\mathrm{C}} \mathrm{xA}}}=\frac{\mathrm{T}_{1}-\mathrm{T}_{4}}{\mathrm{R}_{\mathrm{A}}+\mathrm{R}_{\mathrm{B}}+\mathrm{R}_{\mathrm{C}}}=\frac{\Delta \mathrm{T}}{\Sigma \mathrm{R}_{\mathrm{n}}}
$$

$\mathrm{T}_{1}=\mathrm{T}_{4}$ merupakan perbedaaan temperatur antara ruang yang sudah mengalami kebakaran dengan ruangan yang belum mengalami kebakaran. Sedangkan $R_{A}, R_{B}, R_{C}$, merupakan tahanan masing-masing material. 


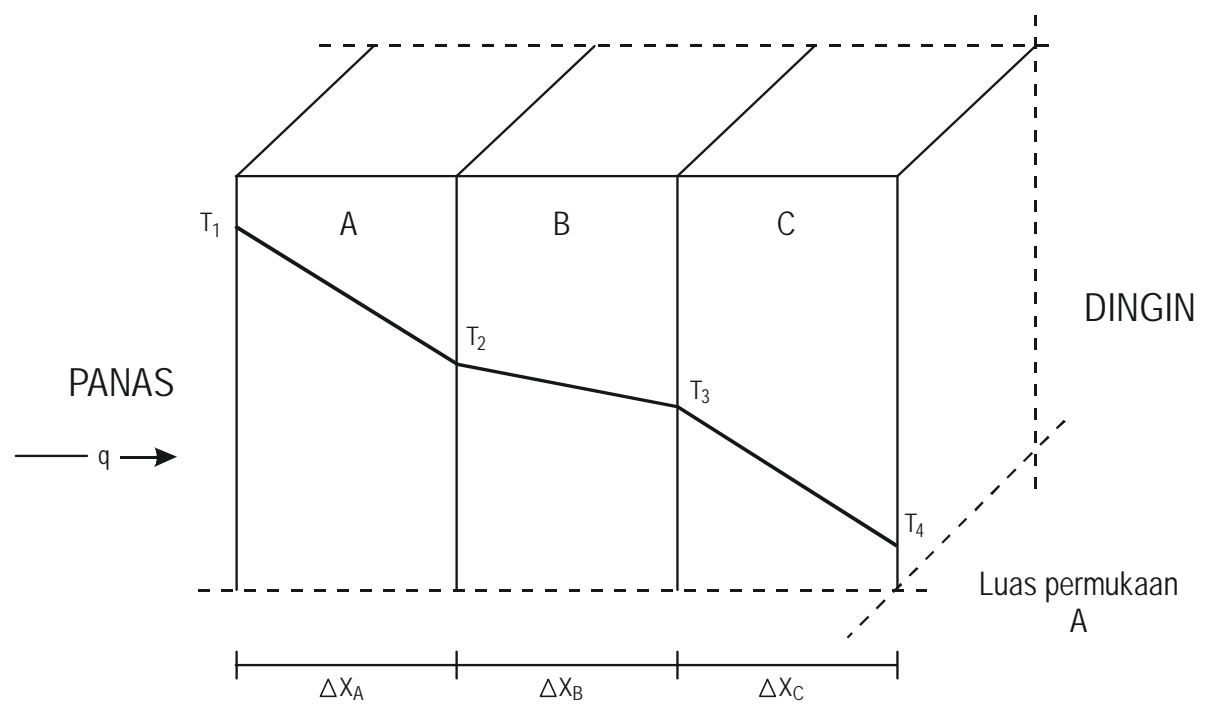

Gambar 15 Aliran panas melalui dinding yang berlapis

Konstanta pembanding $\mathrm{K}$ adalah sifat fisik bahan yang disebut konduktifitas panas (thermal conductivity). Butcher memberikan nilai $\mathrm{K}$ untuk beberapa material bangunan pada Tabel 1. Nilai K yang terdapat dalam tabel tersebut dipandang cukup akurat pada saat kebakaran terjadi dalam bangunan.

Tabel 1 Harga K untuk beberapa material bangunan menurut Butcher

\begin{tabular}{|l|l|}
\hline Material & Thermal conductivity, $k$ (W m-1 K-1 ) \\
\hline
\end{tabular}

\begin{tabular}{|c|c|}
\hline Pasangan batubata & 0.24 \\
\hline Cork slab & 0.042 \\
\hline Beton & 1.83 \\
\hline Asbes & 0.40 \\
\hline Aspal & 1.20 \\
\hline Plesteran ( pasir dan semen ) & 0.53 \\
\hline Kayu & 0.17 \\
\hline Plywood & 0.11 \\
\hline Alumunium & 200 \\
\hline Besi & 46 \\
\hline Baja & 41 \\
\hline Stainless steel & 25 \\
\hline
\end{tabular}




\subsection{Radiasi}

Radiasi adalah perpindahan panas melalui gelombang elektromagnetik. Sebagian energi yang dihasilkan dipancarkan ke udara luar dan sebagian lagi diradiasikan ke arah bahan bakar sehingga menambah intensitas kebakaran. Selama kebakaran terjadi, permukaan- permukaan yang panas dapat memancarkan panas, serta menyulut bahan bakar sedapat mungkin dengan jarak yang jauh. Terjadinya radiasi pada bangunan yang terbakar ditunjukkan pada sketsa Gambar 16.

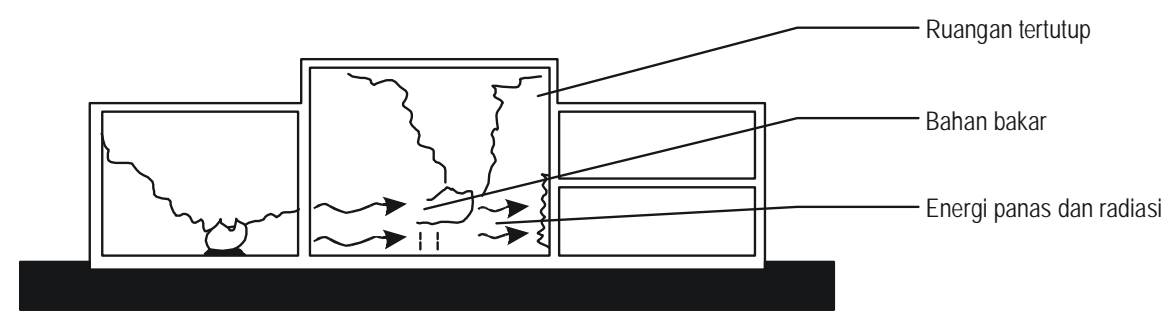

Gambar 16 Radiasi

\section{PENJALARAN KEBAKARAN}

\subsection{Konveksi}

Kecepatan rambatan api vertikal dapat diperkirakan kuantitasnya. Pada umumnya, api vertikal akan meningkat menjadi dua kali total tingginya pada penambahan waktu yang sama, dikenal sebagi pertumbuhan eksponensial. Sebagai contoh bila api dengan ketinggian $25 \mathrm{~cm}$ bisa bertambah tinggi menjadi $50 \mathrm{~cm}$ dalam waktu 50 detik, maka api yang sama dengan tinggi 1,0 $\mathrm{m}$ akan tumbuh hingga 2,0 m pada waktu yang sama yakni 50 detik. Ini yang disebut sebagai waktu dobel (Dobling Time).

Bila waktu dobel suatu bahan diketahui, maka waktu penyebaran vertikal akan dapat diketahui pula. Sebagi contoh, bila waktu dobel suatu bahan adalah 30 detik maka akan dapat dihitung bahwa api setinggi $30 \mathrm{~cm}$ akan berubah sampai mencapai ketinggian dinding 19 m setelah 30 menit. Efek dobel ini diperlihatkan pada Gambar 17. 


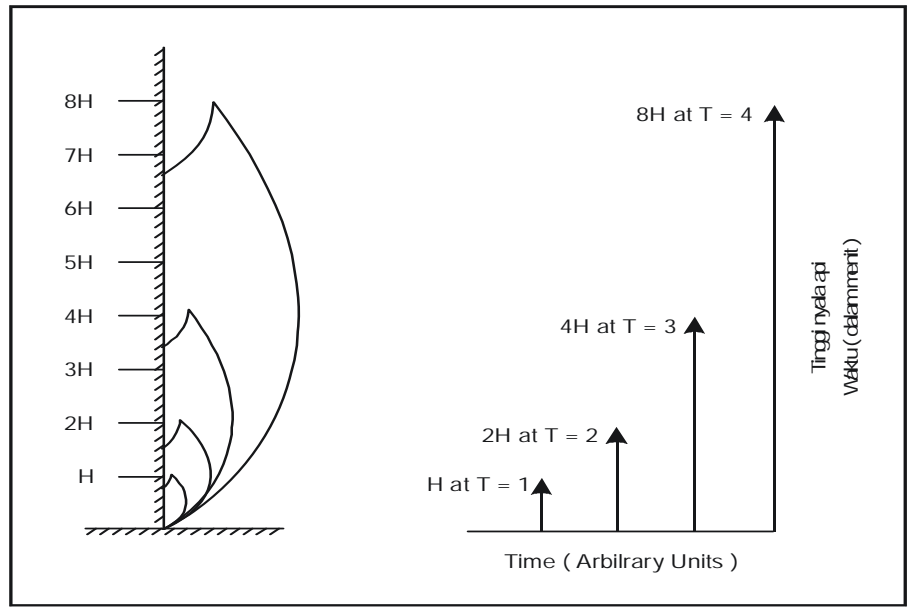

Gambar 17 Efek dobel pada permukaan vertikal

Pertumbuhan api secara eksponensial pada permukaan vertikal ini dipengaruhi oleh jenis bahan terbakar. Tiap jenis bahan memilki waktu dobel tertentu yang relatif tetap pada rentang ketinggian $0,6 \mathrm{~m}-3$ atau $4 \mathrm{~m}$. Namun adanya nyala api lain seperti misalnya pada dinding yang berhadapan atau radiasi pancaran benda terbakar lainnya, akan dapat menurunkan waktu dobel sehingga mempercepat penyebaran api ke atas.

\subsection{Penjalaran Api Pada Permukaan Horisontal}

Api menyebar diatas permukaan horizontal. Permukaan bahan padat yang berada pada bagian belakang lintasan nyala api akan terbakar akibat panas balik dari zona pembakaran. Uap bahan bakar yang terbakar akan bergerak ke depan, akibat bertambah tinggi temperaturnya ketika mendekati nyala api. Selanjutnya jika uap bahan bakar mencapai temperatur yang cukup untuk penyalaan dan memperoleh oksigen dengan level yang cukup untuk pembakaran, maka timbulah penyalaan dan menjadi bagian dari nyala api yang tengah berlangsung tersebut. Gambar 18 memperlihatkan mekanisme penyebaran api horizontal 


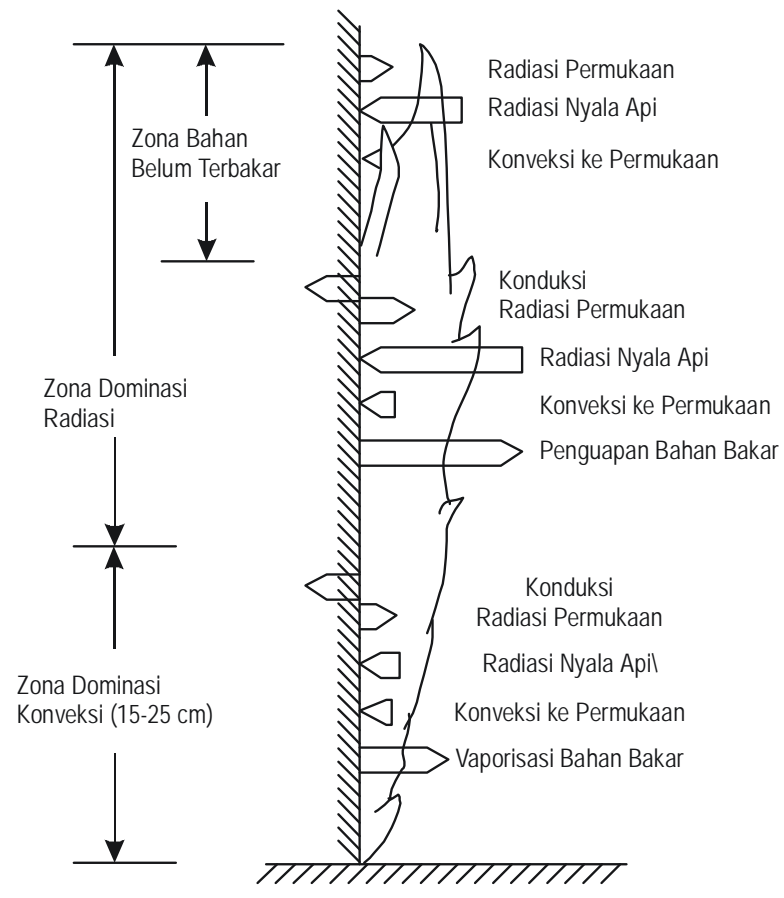

Gambar 18 Keseimbangan energi pada penyebaran api arah vertikal

\subsection{Penjalaran Kebakaran Dari Ruangan Ke Ruangan Pada Suatu Bangunan}

Penjalaran kebakaran dari ruangan ke ruangan lain pada suatu bangunan dapat terjadi sebelum dinding pada ruangan tersebut mengalami kehancuran. Berdasarkan percobaan yang dilakukan Gross dan Plumer, suatu dinding yang terbuat dari batu bata setebal 4 inci dan plesteran pada kedua sisi setebal 1 inci mempunyai fire resistance selama 2 jam. Namun sebelum fire resistance dilampaui, telah terjadi perpindahan panas secara konduksi melalui dinding. Dengan adanya panas yang dipindahkan ke ruangan lain, maka secara konveksi dan radiasi akan menyebabkan kebakaran lagi pada ruangan lagi. Perpindahan panas tidak hanya terjadi melalui dinding, tetapi dapat juga melalui ventilasi dan pintu. 


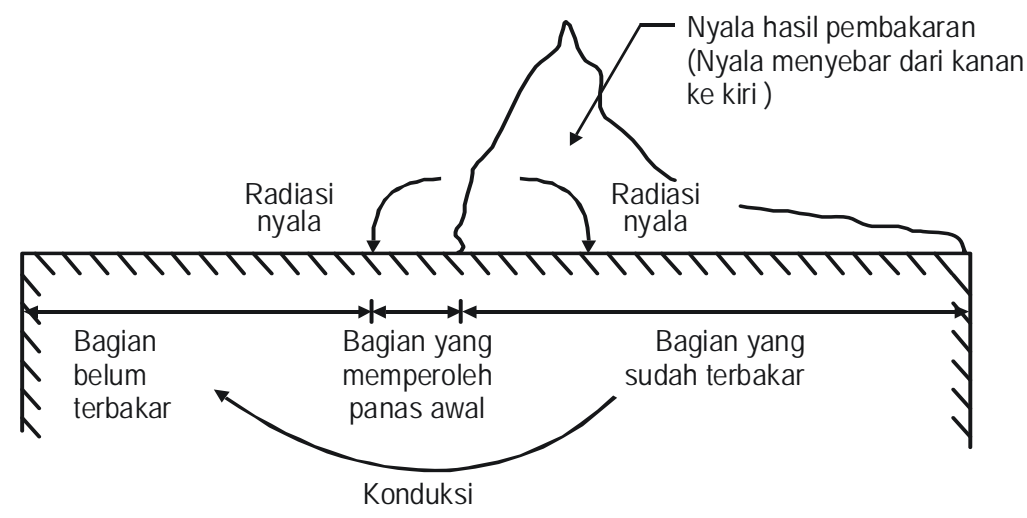

Gambar 19 Penyebaran nyala api horizontal pada permukaan benda

Sehingga untuk mencegah menjalarnya kebakaran secara cepat dan diusahakan agar kebakaran tersebut dikurung pada suatu ruangan maka dibuatlah kompartemen. Kompartemen (compartment) adalah bagian dari bangunan yang dipisahkan satu sama lain oleh satu atau lebih dinding tahan api, lantai tahan api atau dinding dan lantai tahan api, dengan maksud mencegah perluasan api antara bangunan yang merupakan kompartemen

Pada kenyataan yang ada, kompartemen dibuat pada tempat-tempat tertentu saja. Untuk menentukan letak kompartemen tersebut maka harus diperkirakan arah penjalaran kebakaran yang mungkin terjadi.

\subsection{Penjalaran Kebakaran Dari Lantai Ke Lantai Pada Suatu Bangunan}

Kebakaran dapat menjalar ke bagian lantai atas, dalam satu bangunan yang sama, akibat lidah api yang muncul dari opening. Opening yang dimaksud dalam hal ini adalah jendela. Penyalaan suatu benda pada lantai atas dapat terjadi, apabila benda tersebut berada di dekat jendela, dan memungkinkan lidah api tersedot ke dalam ruangan melalui jendela yang terbuka atau seluruh kacanya telah pecah.

Perilaku dari lidah api yang muncul dari jendela telah dipelajari, dan hasil yang menarik serta penting telah menunjukan bahwa bentuk lidah api tergantung pada desain bangunan, yaitu dimensi jendela.

Pada Gambar 20 diperlihatkan pengaruh dimensi jendela terhadap panjang lidah api. Pada jendela yang mempunyai dimensi $2 \mathrm{~m}$ x $6,4 \mathrm{~m}$, temperatur lidah api yang keluar melalui jendela adalah $600^{\circ} \mathrm{C}$. Setelah mencapai bagian bawah jendela lantai atas, temperaturnya menurun menjadi $500^{\circ} \mathrm{C}$. Semakin ke atas temperatur lidah api menurun hingga mencapai $300^{\circ} \mathrm{C}$. Selebihnya, temperatur di bawah $300^{\circ} \mathrm{C}$ merupakan asap dan 
gas panas. Butcher menggolongkan bahwa temperatur lidah api antara $300^{\circ} \mathrm{C}$ hingga $600^{\circ} \mathrm{C}$ adalah berbahaya dan mempunyai kemungkinan untuk terjadinya penjalaran kebakaran.

Pada dua jendela yang berdimensi lain, diperlihatkan posisi temperatur lidah api terhadap ketinggian jendela tiap-tiap lantai adalah berbeda-beda. Bahaya terkecil adalah jendela sama sisi yang berdimensi 2 × $2 \mathrm{~m}$.

Kesimpulan yang di dapat dari contoh tersebut menyatakan bahwa dimensi jendela seharusnya sekecil mungkin. Penambahan tinggi atau lebar akan meningkatkan penjalaran kebakaran oleh lidah api yang keluar dari jendela.

\section{a. Memperkirakan Kecepatan Panas Yang Dilepas Melalui Opening}

Kecepatan panas yang dilepas dari opening pada suatu ruangan selama kebakaran dapat ditentukan dengan memperhitungkan kandungan panas dari gas-gas panas yang mengalir keluar. Jika $\mathrm{R}$ adalah kecepatan membakar suatu material dan $\mathrm{G}_{0}$ adalah volume pada $0^{0} \mathrm{C}$ dari gas yang dihasilkan pembakaran tiap satuan waktu adalah $\mathrm{G}_{0} \mathrm{xR}$. Gas ini mengandung energi panas yang mengalir keluar opening. Jika Cp' adalah volume spesifik panas gas dan Tr adalah perbedaan temperatur antara gas dan udara sekitar maka panas yang dilepas setiap satuan waktu dari opening adalah

$$
\mathrm{Q}=\mathrm{Cp}^{\prime} \times \mathrm{G}_{0} \times \mathrm{R} \times \Delta \mathrm{Tr}
$$

Sebagai contoh, untuk jumlah panas yang dihasilkan oleh pembakaran $1 \mathrm{~kg}$ kayu akan tergantung pada kondisi pembakaran, dimana pembakaran yang sempurna menghasilkan gas yang lebih banyak. Yokoi mengasumsikan bahwa kondisi pembakaran yang menghasilkan gas tiap kg kayu dikonversikan kedalam volume $\mathrm{G}_{0}$ pada $0^{0} \mathrm{C}$ adalah mendekati $4,85 \mathrm{~m}^{2} / \mathrm{kg}$. Untuk harga panas spesifik digunakan $\mathrm{Cp}^{\prime}=0,32 \mathrm{kkal} / \mathrm{m}^{3}{ }^{0} \mathrm{C}$. Untuk harga $\mathrm{G}_{0}$ dan $\mathrm{Cp}$ ' tersebut, Persamaan 19 menjadi

$$
\mathrm{Q}=1550 \times \mathrm{R} \times \Delta \operatorname{Tr} \quad \mathrm{kal} / \mathrm{detik}
$$




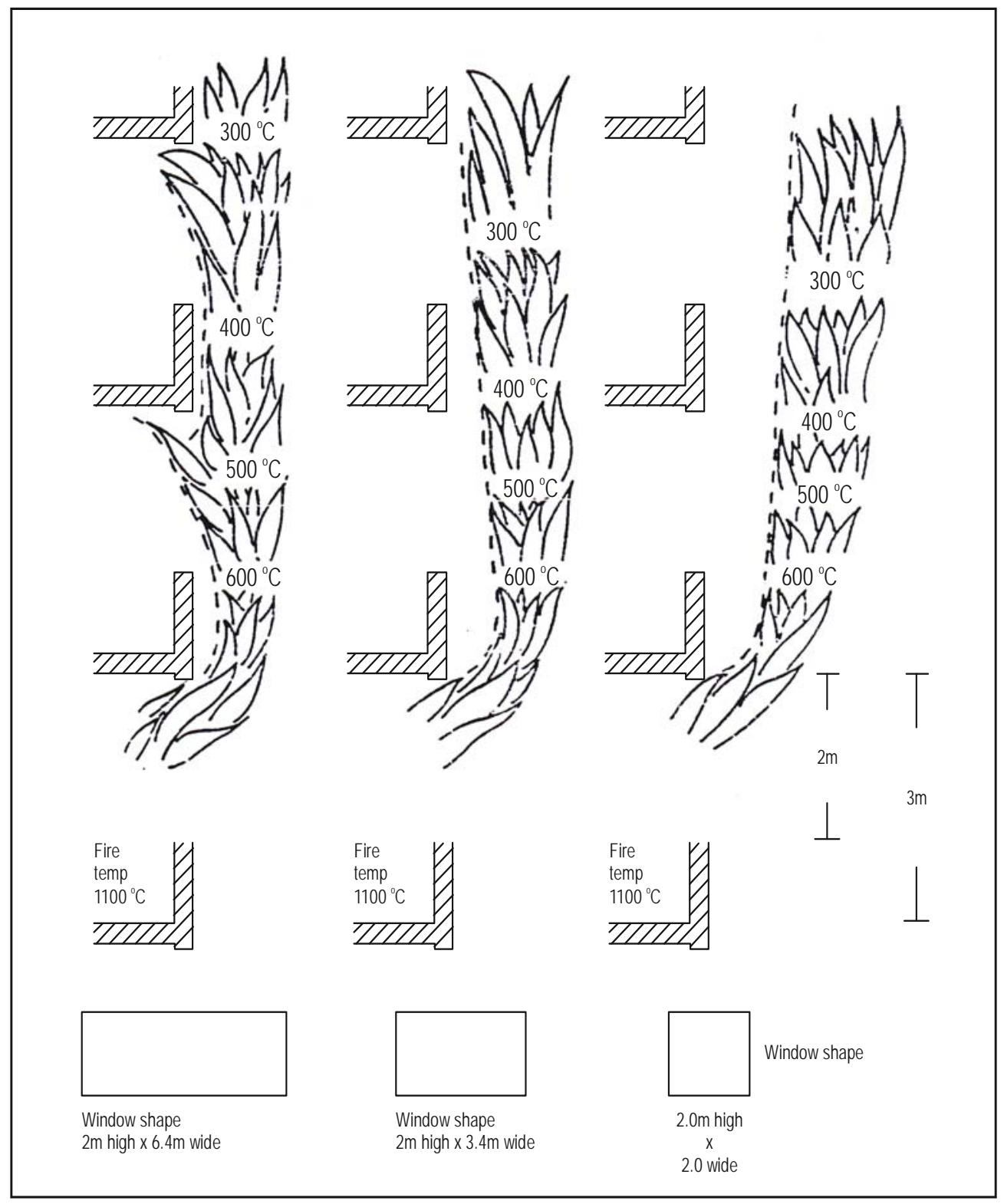

Gambar 20 Profil dan temperatur lidah api untuk jendela dengan ukuran tinggi $2 \mathrm{~m}$ dan lebar yang berbeda

Seperti telah dibahas sebelumnya bahwa kecepatan membakar material adalah

$$
\begin{aligned}
& \mathrm{R}=5,5 \times \mathrm{A} \sqrt{\mathrm{H}} \mathrm{kg} / \text { menit } \\
& \mathrm{R}=0,092 \mathrm{~A} \sqrt{\mathrm{H}} \mathrm{kg} / \text { detik }
\end{aligned}
$$

Substitusikan persamaan 22 ke persamaan 20 akan menghasilkan persamaan kecepatan panas yang dilepas melalui opening sebagai berikut:

$$
\mathrm{Q}=143 \mathrm{~A} \sqrt{ } \mathrm{H} \Delta \mathrm{T}_{\mathrm{r}} \quad \mathrm{kal} / \mathrm{detik}
$$


Atau jika A dan $\mathrm{H}$ dinyatakan dalam cm maka

$$
\mathrm{Q}=143 \times 10^{-5} \mathrm{~A} \sqrt{\mathrm{H}} \Delta \mathrm{Tr} \quad \mathrm{kal} / \mathrm{detik}
$$

b. Jari-jari Jendela Ekivalen

Suatu opening yang merupakan bagian dari ruangan yang terbakar dan menyebabkan terjadinya pelepasan panas, dapat dinyatakan bahwa opening tersebut merupakan sumber panas. Bila opening yang dimaksud adalah jendela dan berbentuk persegi dinamakan rectangular heat source, dan bila berbentuk lingkaran dinamakan circular heat source. Berdasarkan hasil percobaan yang dilakukan Yokoi, bahwa panas yang keluar dari jendela, mempunyai penampang yang menyerupai bentuk lingkaran. Sehingga pada penentuan distribusi temperatur lidah api, diperlukan pendekatan jari-jari penampang tersebut. Apabila jendela tersebut berbentuk lingkaran maka jari-jari penampang tersebut adalah sama dengan jari-jari jendela. Tetapi pada umumnya jendela selalu berbentuk persegi, sehingga diperlukan jari-jari penampang yang ekivalen dengan jari-jari jendela yang berbentuk persegi. Oleh Yokoi, jari-jari ekivalen jendela tersebut dapat dianalisis dengan persamaan sebagai berikut

$$
\mathrm{r}_{0}^{2}=\left(\mathrm{na}^{2}\right) / \pi
$$

di mana ;

$$
\mathrm{r}_{0}=\text { jari-jari ekivalenjendela, } \mathrm{a}=0,5 \mathrm{H}, \text { dan } \mathrm{n}=\text { rasio lebar jendela dengan } \mathrm{n}=\mathrm{B} / \mathrm{a}
$$

\section{c. Distribusi Temperatur Lidah Api}

Distribusi temperatur lidah api menurut Yokoi ditentukan dengan persamaan sebagai berikut

$$
\mathrm{v}=\mathrm{T}\left[\frac{\mathrm{g} \mathrm{C} p^{2} \rho^{2} \mathrm{r}_{0}^{5}}{\mathrm{Q}^{2} \mathrm{~T}_{0}}\right]^{1 / 3}
$$

dimana:

$$
\begin{aligned}
\mathrm{v}= & \text { distribusi temperatur sepanjang lintasan yang mempunyai temperatur } \\
& \text { lebih besar atau sama dengan } \mathrm{T} \\
\mathrm{T}= & \text { temperatur lidah api yang dipertimbangkan } \\
\mathrm{T}_{0}= & \text { temperatur absolut lingkungan sekitar }=27^{\circ} \mathrm{C} \\
\rho= & \text { rapat massa gas yang mengalir keluar } \\
\mathrm{Cp}= & \text { panas spesifik dari gas yang mengalir keluar pada tekanan konstan } \\
\mathrm{g}= & \text { percepatan gravitasi } \\
\mathrm{r}_{0}= & \text { jari-jari ekivalen jendela }
\end{aligned}
$$


Yokoi memberikan nilai $\mathrm{Cp}=0,24 \mathrm{kal} / \mathrm{g}, \rho=0,000456 \mathrm{~g} / \mathrm{cm}^{3}$ dan $\mathrm{g}=980 \mathrm{~cm} / \mathrm{s}^{2}$, sehingga persamaan 2.26 berubah menjadi;

$$
\mathrm{v}=3,395 \times 10^{-3} \times \mathrm{T} \times\left[\frac{\mathrm{r}_{0}{ }^{5}}{\mathrm{Q}^{2}}\right]^{1 / 3}
$$

Setelah distribusi temperatur (v) didapat maka dapat diketahui rasio panjang lidah api dengan jari-jari ekivalen $\left(\mathrm{Z} / \mathrm{r}_{0}\right)$ melalui Tabel 2 Panjang lidah api $(\mathrm{Z})$ yang dimaksud adalah panjang dari bagian lidah api yang mempunyai temperatur di atas $\mathrm{T}^{0} \mathrm{C}$.

Tabel 2 Nilai Z/r0 dari hasil percobaan Yokoi (1960) sebagai suatu fungsi dari v sepanjang lintasan lidah api yang keluar dari jendela

\begin{tabular}{|c|c|c|c|c|c|c|c|}
\hline $\mathbf{v}$ & $\mathbf{Z} / \mathbf{r}_{\mathbf{o}}$ & $\mathbf{v}$ & $\mathbf{Z} / \mathbf{r}_{\mathbf{o}}$ & $\mathbf{v}$ & $\mathbf{Z} / \mathbf{r}_{\mathbf{o}}$ & $\mathbf{v}$ & $\mathbf{Z} / \mathbf{r}_{\mathrm{o}}$ \\
\hline 0.46 & 0.20 & 0.30 & 2.40 & 0.46 & 0.20 & 0.30 & 2.40 \\
\hline 0.45 & 0.25 & 0.29 & 2.60 & 0.45 & 0.25 & 0.29 & 2.60 \\
\hline 0.445 & 0.30 & 0.28 & 2.75 & 0.445 & 0.30 & 0.28 & 2.75 \\
\hline 0.44 & 0.40 & 0.27 & 2.90 & 0.44 & 0.40 & 0.27 & 2.90 \\
\hline 0.43 & 0.50 & 0.26 & 3.10 & 0.43 & 0.50 & 0.26 & 3.10 \\
\hline 0.425 & 0.60 & 0.255 & 3.30 & 0.425 & 0.60 & 0.255 & 3.30 \\
\hline 0.42 & 0.70 & 0.245 & 3.50 & 0.42 & 0.70 & 0.245 & 3.50 \\
\hline 0.41 & 0.80 & 0.235 & 3.70 & 0.41 & 0.80 & 0.235 & 3.70 \\
\hline 0.40 & 0.90 & 0.23 & 3.90 & 0.40 & 0.90 & 0.23 & 3.90 \\
\hline 0.39 & 1.00 & 0.22 & 4.10 & 0.39 & 1.00 & 0.22 & 4.10 \\
\hline 0.38 & 1.10 & 0.21 & 4.40 & 0.38 & 1.10 & 0.21 & 4.40 \\
\hline 0.37 & 1.20 & 0.20 & 4.70 & 0.37 & 1.20 & 0.20 & 4.70 \\
\hline 0.36 & 1.30 & 0.19 & 5.00 & 0.36 & 1.30 & 0.19 & 5.00 \\
\hline 0.35 & 1.50 & 0.18 & 5.40 & 0.35 & 1.50 & 0.18 & 5.40 \\
\hline 0.34 & 1.70 & 0.17 & 5.80 & 0.34 & 1.70 & 0.17 & 5.80 \\
\hline 0.33 & 1.90 & 0.16 & 6.30 & 0.33 & 1.90 & 0.16 & 6.30 \\
\hline 0.32 & 2.05 & 0.15 & 6.80 & 0.32 & 2.05 & 0.15 & 6.80 \\
\hline 0.31 & 2.20 & 0.14 & 7.40 & 0.31 & 2.20 & 0.14 & 7.40 \\
\hline
\end{tabular}

Tabel 3 Harga Thermal Conductivity udara untuk berbagai temperatur udara*

\begin{tabular}{|cccc|}
\hline $\begin{array}{c}\text { Temp } \\
(\mathbf{K})\end{array}$ & $\begin{array}{c}\text { Udara } \\
\left(\mathbf{W m}^{-\mathbf{1}} \mathbf{K}^{\mathbf{- 1}} \mathbf{)}\right.\end{array}$ & $\begin{array}{c}\text { Temp } \\
\mathbf{( K )}\end{array}$ & $\begin{array}{c}\text { Udara } \\
\left(\mathbf{W} \mathbf{m}^{-\mathbf{1}} \mathbf{K}^{\mathbf{- 1}} \mathbf{)}\right.\end{array}$ \\
\hline 100 & 0,0093 & 500 & 0,0407 \\
150 & 0,0138 & 600 & 0,0469 \\
200 & 0,0180 & 700 & 0,0524 \\
250 & 0,0221 & 800 & 0,0573 \\
300 & 0,0262 & 900 & 0,0620 \\
350 & 0,0300 & 1000 & 0,0667 \\
400 & 0,0338 & 1200 & 0,0763 \\
450 & 0,0373 & 1300 & 0,0788 \\
\hline
\end{tabular}


*Derry,Robert H. and Don W. Green, Perry's Chemical Engineers Handbook $6^{\text {th }}$ ed,Mc Graw-Hill,Inc.,New York,1984,sect 3,pp.254

Tabel 4 Fire Load Density Berdasarkan Fungsi Bangunan

\begin{tabular}{|lc|} 
Fungsi Bangunan & Fire Load Density $\left(\mathrm{kg} / \mathrm{m}^{2}\right)$ \\
\hline Tempat kediaman & 25 \\
Institusional & 25 \\
Kantor & $25-50$ \\
Pertokoan & lebih besar dari 250 \\
Pabrik & lebih besar dari 150 \\
Tempat pertemuan & $25-50$ \\
\hline
\end{tabular}

\section{Simpulan dan Saran}

Kesimpulan:

1. Pemahaman sifat sifat api/panas sangat perlu dipahami. .

2. Perlu diketahui tahapan pembakaran bila terjadi kebakaran di dalam gedung.

3. Perlu diketahui bagaimana cara memadamkan api, bila terjadi kebakaran.

Saran:

Untuk semua pengelola gedung diperlukan pengetahuan mengenai sumber sumber panas yang dapat menyebabkan terbakarnya gedung serta pengetahuan mengenai cara penanggulangan api/panas bila terjadi kebakaran.

\section{Daftar Pustaka:}

1. Kaskus (2014),Fire \& Safety Engineering Building.

2. Susan K Grove,Kjenniver R Gray,Nancy Burns (2014),Understanding Nursing Research, An Evidence-Based. 